\title{
Antileukemic T-cell Responses Can Be Predicted by the Composition of Specific Regulatory T-cell Subpopulations
}

\author{
Julia Schick,* Valentin Vogt,* Marion Zerwes, $\dagger$ Tanja Kroell,* \\ Doris Kraemer, $\neq$ Claus-Henning Köhne, $\neq$ Andreas Hausmann, ${ }^{*}$ \\ Raymund Buhmann, ${ }^{*}+$ Johanna Tischer, ${ }^{*}$ and Helga Schmetzer* ${ }^{*}$
}

\begin{abstract}
Summary: Regulatory $\mathrm{T}$ cells $\left(\mathrm{T}_{\mathrm{reg}}\right)$ are important regulators of immune responses. In acute myeloid leukemia (AML) patients before/after immunotherapy (stem cell transplantation or donor lymphocyte infusion), their suppressive role can contribute to suppress severe graft-versus-host reactions, but also to impair antileukemic reactions. As leukemia-derived dendritic cells $\left(\mathrm{DC}_{\text {leu }}\right)$ are known to improve the antileukemic functionality of $\mathrm{T}$ cells, we evaluated the composition and development of distinct $\mathrm{T}_{\text {reg }}$ subtypes in AML patients $(\mathrm{n}=12)$ compared with healthy probands $(\mathrm{n}=5)$ under unstimulated conditions and during stimulation with $\mathrm{DC}_{\mathrm{leu}}$-containing DC (DC) or blast-containing mononuclear cells (MNC) in 0- to 7-day mixed lymphocyte cultures by flow cytometry. T-cell subgroups in AML patients were correlated with antileukemic functionality before and after DC or MNC stimulation by functional fluorolysis assays. (1) AML patients' T cells presented with significantly higher frequencies of $\mathrm{T}_{\text {reg }}$ subgroups in unstimulated $\mathrm{T}$ cells compared with healthy probands. (2) After 7 days of DC or MNC stimulation, all $\mathrm{T}_{\text {reg }}$ subtypes generally increased; significantly higher frequencies of $\mathrm{T}_{\text {reg }}$ subtypes were still found in AML patients. (3) Antileukemic cytotoxicity was achieved in $36 \%$ of T cells after MNC compared with $64 \%$ after DC stimulation. Antileukemic activity after DC but not after MNC stimulation correlated with significantly lower frequencies of $\mathrm{T}_{\text {reg }}$ subtypes $\left(C D 8^{+} T_{\text {reg }} / T_{\text {eff/em reg }}\right)$. Furthermore, cut-off values for $T_{\text {reg }}$ subpopulations could be defined, allowing a prediction of antileukemic response. We demonstrate a crucial role of special $\mathrm{T}_{\text {reg }}$ subtypes in the mediation of antileukemic functionality. High $\mathrm{CD}^{+} \mathrm{T}_{\text {reg }}$, $\mathrm{T}_{\text {eff } / \mathrm{em} \mathrm{reg}}$, and $\mathrm{CD} 39^{+} \mathrm{T}$ cells correlated clearly with a reduced antileukemic activity of $\mathrm{T}$ cells. DC stimulation of $\mathrm{T}$ cells contributes to overcome impaired antileukemic $\mathrm{T}$-cell reactivity. Refined analyses in the context of clinical responses to immunotherapies and graft versus host reactions are required.
\end{abstract}

Key Words: AML, regulatory T cells, dendritic cells, immune escape

(J Immunother 2013;36:223-237)

A cute myeloid leukemia (AML) and myelodysplastic syndromes (MDS) are clonal disorders of hematopoietic stem cells characterized by an impaired cell

Received for publication July 2, 2012; accepted December 10, 2012

From the *Department for Hematopoietic Cell Transplantation, Medicine Department 3, University Hospital of Munich; $\dagger$ Helmholtz Center Munich (German Research Center for Environmental Health and Clinical Cooperative Group Hematopoetic Cell-Transplantation), Munich; and \$Department for Hematology and Oncology, Municipal Hospital, Oldenburg, Germany.

J.S. and V.V. contributed equally.

Reprints: Helga Schmetzer, Department for Hematopoietic Cell Transplantation, Medicine Department 3, Klinikum Grosshadern, University of Munich, Marchioninistr.15, 81377 Munich, Germany (e-mail: helga.schmetzer@med.uni-muenchen.de).

Copyright (C) 2013 by Lippincott Williams \& Wilkins differentiation. ${ }^{1}$ Although up to $70 \%-80 \%$ of patients younger than 60 years of age achieve a complete remission with induction therapy, the 2-year survival is only about $46 \%{ }^{2}$ Despite intensive treatment options such as highdose chemotherapy, stem cell transplantation (SCT), and transfusion of Donor $\mathrm{T}$ cells to maintain the antileukemic function, the rate of relapse or persistence of the disease is still unsatisfying in patients with AML.

Until now, several soluble or cellular factors are known that regulate immune mechanisms in healthy individuals. However, in tumor patients, unbalanced regulatory mechanisms can contribute to immune escape mechanisms through which leukemic blasts can escape the killing by the immune system ${ }^{3}$ : downregulation of HLA class I expression on tumor cells ${ }^{4}$ or a defective antigen processing and expression on tumor cells protect them from elimination by cytotoxic T lymphocytes (CTL). ${ }^{5}$ Another escape mechanism uses the disruption of the Fas/FasL system, which induces apoptosis. Furthermore, soluble factors such as the immunosuppressive cytokines interleukin (IL)-10 or tumor growth factor- $\beta$, or FasL and 4-1BBL released by T cells, dendritic cells (DC), or tumor cells can limit the immune surveillance because of insufficient lymphocyte stimulation in an inhibitory microenvironment. ${ }^{6,7}$ Moreover, we and others have already shown that regulatory soluble factors produced by host $\mathrm{T}$ cells or DC contribute to the regulation and mediation of antileukemic T-cell function. ${ }^{3}$ Moreover, cellular factors such as regulatory $T$ cells $\left(T_{\text {reg }}\right)$ consisting of naturally occurring $T_{\text {reg }}$ and several subgroups of extrathymically activation-induced $T_{\text {reg }}$ are known to regulate immune responses. $T_{\text {reg }}$ are classically divided into naturally occurring $\mathrm{CD}^{+} \mathrm{CD} 25^{+} \mathrm{FOXP}^{+} \mathrm{T}_{\text {reg }}\left({ }_{n} \mathrm{~T}_{\text {reg }}\right)$ and activation-induced $\mathrm{T}_{\text {reg }}\left(\mathrm{T}_{\mathrm{i}}\right.$ reg $)$ appearing after peripheral antigen stimulation. ${ }^{8}{ }_{\mathrm{i}} \mathrm{T}_{\text {reg }}$ can belong to $\mathrm{CD} 4^{+}$and $\mathrm{CD} 8^{+}$ $\mathrm{T}$ cells, whereas ${ }_{n} \mathrm{~T}_{\text {reg }}$ belong only to $\mathrm{CD}^{+}{ }^{+} \mathrm{T}$ cells, and form about $1 \%-2 \%$ of the peripheral blood cells. ${ }^{9}$ From a clinical point of view, $\mathrm{T}_{\text {reg }}$ is a 2-edged sword. On the one hand, $\mathrm{T}_{\text {reg }}$ physiologically maintain the peripheral immune tolerance and are able to prevent excessive immune responses in allergy or autoaggressive immune reactions in autoimmune diseases, transplantations, or graft-versus-host disease. ${ }^{10-13}$ In humans suffering from the IPEX (immune dysregulation, polyendocrinopathy, enteropathy, X-linked) syndrome, a mutation in the FOXP3 gene leads to a deficiency of $T_{\text {reg }}$ function with severe clinical autoimmune inflammatory disease. ${ }^{14,15}$ On the other hand, increased amounts of $\mathrm{T}_{\text {reg }}$ can diminish effective antitumor $\mathrm{T}$-cell responses in patients with cancer. ${ }^{16-18}$ In the past years, several attempts have been made to identify specific $T_{\text {reg }}$ markers and to determine the mechanisms of $T_{\text {reg }}$ function. Originally, regulatory $\mathrm{T}$ cells were defined as " $\mathrm{CD} 8^{+}$ 
suppressor T cells" and later on as $\mathrm{CD} 25^{+} \mathrm{CD} 4{ }^{+} \mathrm{T}$ cells. ${ }^{19} \mathrm{~A}$ more specific marker was found with the identification of the transcription factor FOXP3 and its key role in the development and function of $\mathrm{T}_{\text {reg. }}{ }^{20,21}$ In addition, surface markers such as CTLA-4 (CD152 $\left.{ }^{+}\right), \mathrm{LAG} 3, \mathrm{CD} 39^{+} \mathrm{CD}^{+} 3^{+}$, and a low expression of the IL-7 receptor (CD127 low $)$ have contributed to a refined definition of $\mathrm{T}_{\text {reg. }}$. A common disadvantage of all of these markers is their potentially "unspecific" upregulation during the activation of $\mathrm{CD}^{+} \mathrm{T}$ cells. ${ }^{22}$ Regarding the function of $\mathrm{T}_{\text {reg }}, 4$ basic mechanisms are postulated for their suppressive function including their production of inhibitory cytokines such as tumor growth factor- $B$ and IL-10, ${ }^{23,24}$ their potential of a granzyme Bdependent cytolysis, ${ }^{25}$ their potential to downregulate IL-2mediated metabolism and immunosuppressive adenosines generated through the hydrolysis of ATP by the ectoenzymes $\mathrm{CD}^{2} 9^{+}$and $\mathrm{CD} 73^{+, 26,27}$ and their suppression of DC-mediated T-cell stimulation through the upregulation of CD152+28

Recent findings of our group showed that an inhibitory microenvironment as established by blasts can impair an antileukemic T-cell response, but can be overcome by the conversion of leukemic blasts to leukemia-derived DC $\left(\mathrm{DC}_{\text {leu }}\right) .{ }^{29}$ Furthermore, we could work out relevant soluble factors (eg, released cytokines) or cells (eg, amounts of $\mathrm{DC}_{\text {leu }}$ and mature DC) that are important and predictive key players in the successful mediation of antileukemic, cytotoxic T cells or the clinical response to immunotherapy. However, there are still cases where no antileukemic function of T cells after DC stimulation could be achieved. ${ }^{30,31}$ Thus, the aims of this study were as follows: (1) to evaluate compositions of several $\mathrm{T}_{\text {reg }}$ subgroups (eg, CD4 ${ }^{+} \mathrm{T}_{\text {reg, }}$, $\mathrm{CD}^{+} \mathrm{T}_{\text {reg }}, \mathrm{T}_{\text {naive }}$ reg ) in uncultured peripheral bloodmononuclear cells from healthy probands and AML patients; (2) to investigate the development and recruitment of $\mathrm{T}_{\text {reg }}$ subgroups during the stimulation of $\mathrm{T}$ cells with $\mathrm{DC}_{\mathrm{leu}}$-containing DC ('DC') or blast-containing mononuclear cells ('MNC') in AML patients compared with healthy probands; (3) to correlate T-cell expression profiles with the antileukemic function of 'DC'-stimulated or 'MNC'-stimulated T cells in AML patients; and (4) to evaluate potential antileukemically predictive values of $\mathrm{T}_{\text {reg }}$ subgroups.

\section{MATERIALS AND METHODS}

\section{Sample Collection}

After obtaining informed consent, heparinized blood samples were taken from patients. MNCs were isolated from whole blood samples by density gradient centrifugation (Ficoll-Hypaque; Biochrom, Berlin, Germany), and then washed and suspended in phosphate-buffered saline without $\mathrm{Ca}_{2}^{+}$and $\mathrm{Mg}_{2}^{+}$(Biochrom). Cell counts were quantified by Neubauer counting chambers, frozen with standardized procedures, and stored in liquid nitrogen until use.

\section{Patients' Characteristics and Diagnostics}

Diagnosis of AML and MDS cases was based on the French-American-British (FAB) classification. Samples from 12 patients with AML in acute stages of the disease were used as sources for DC generation. Sources for T cells were healthy stem cell donors ("donors," $\mathrm{n}=1$ ), patients before SCT, all of them in active stages of the disease ("autologous," $\mathrm{n}=6$ ), or patients after SCT ("after SCT", $\mathrm{n}=5$ ), with 3 of them in remission and 2 of them at relapse after SCT (Table 1). Patients' age at diagnosis was on average 48 years (range, 5-70y), and the female to male ratio was $1: 1$. Three patients presented with undifferentiated leukemia (M0 n =2, M1 n =2) and 1 with immature granulocytic leukemia (M2 $\mathrm{n}=1)$. Monocytic leukemia was diagnosed in 6 patients (M4 n =4, M5 $\mathrm{n}=1$ ). The 1 MDS case was a chronic myelomonocytic

TABLE 1. Patients' and Samples' Characteristics

Patients' Characteristics at the

Time Point of T-cell Preparation

Antileukemic Activity (\%) of

Unstimulated (u), MNC

('MNC')-stimulated or

DC-stimulated

T Cells ('DC')

Patients' Characteristics at the Time Point of DC Generation

\begin{tabular}{|c|c|c|c|c|c|c|c|c|}
\hline $\begin{array}{l}\text { Patient } \\
\text { No. }\end{array}$ & FAB-type & Stage & $\begin{array}{c}\text { Blast Phenotype } \\
\text { (CD) }\end{array}$ & $\begin{array}{c}\text { IC } \\
\text { Bla } \%\end{array}$ & $\begin{array}{c}\text { Source of T Cells } \\
\text { and the Stage }\end{array}$ & "u" & 'DC' & 'MNC' \\
\hline m569 & $\mathrm{M} 0$ & pers. & $15,33,13,34,19$ & 11 & CR, after SCT & -60 & -76 & -63 \\
\hline 853 & M0 & rel. a. SCT & $34,33,117$ & 50 & CR, after SCT & +15 & -75 & +10 \\
\hline $\mathrm{m} 761$ & M1 & pers. & $34,117,15,65,2,7,53$ & 95 & $\mathrm{CR}$, after SCT & -30 & +150 & +55 \\
\hline 824 & $\mathrm{M} 1 / \mathrm{M} 2$ & dgn. & $7,13,34,117,123$ & 68 & First diagnosis, autologous & ND & -85 & +100 \\
\hline 748 & M2 & dgn. & $34,33,117,13,38$ & 50 & First diagnosis, autologous & +120 & +700 & +800 \\
\hline 610 & M4 & pers. rel. & $34,4,33,117,13$ & 80 & Stem cell donor, allogenous & +400 & +220 & +260 \\
\hline 855 & M4 & dgn. & $13,33,34,65,117$ & 37 & First diagnosis, autologous & ND & ND & ND \\
\hline 880 & M4 & rel. a. SCT & $33,64,13,15,117,34,7$ & 90 & Relapse, after SCT* & -93 & -51 & -9 \\
\hline 938 & M4 & rel. a. SCT & $34,117,33,4$ & 74 & Relapse, after SCT* & -60 & -77 & -80 \\
\hline 948 & M5 & dgn. & $14,65,15,33$ & 70 & First diagnosis, autologous & +30 & -55 & +20 \\
\hline 887 & $\mathrm{MDS} / \mathrm{CMML}$ & pers. & $33,34,14,64,117$ & 8 & Persisting disease, autologous* & -58 & -12 & -12 \\
\hline 914 & sAML & rel. & $34,33,15,117$ & 47 & Relapse, autologous & +800 & +250 & +350 \\
\hline
\end{tabular}

*T cells harvested at different time points at relapse (patients 880, 938) or during persisting disease (patient 887) and pooled for MLC.

$\dagger$ Negative values: percentual proportions of lysed blasts, positive values: percentual proportions of increased blasts.

AML indicates acute myeloid leukemia; CMML, chronic myelomonocytic leukemias; CR, complete remission; DC, dendritic cells; dgn., diagnosis; IC Bla, immune cytologically detected blasts; MDS, myelodysplastic syndromes; MLC, mixed lymphocyte cultures; MNC, mononuclear cells; ND, no data; pers. rel., persisting relapse; pers., persisting disease; rel. a. SCT, relapse after SCT; rel., relapse; sAML, secondary AML; SCT, stem cell transplantation. 
leukemia (CMML, $\mathrm{n}=1)$ and 1 patient suffered from a secondary AML (sAML $n=1)$ (Table 1). Five healthy probands served as controls.

Flow cytometric analysis of uncultured MNC fractions was performed to quantify the cellular composition of MNC in 12 AML patients and in healthy cell samples. The cellular composition of $\mathrm{MNC}$ in AML patients was $3 \% \pm 2 \%$ B cells, $9 \% \pm 6 \%$ T cells, $2 \% \pm 2 \%$ natural killer cells, $5 \% \pm 6 \%$ monocytes, and $56 \% \pm 25 \%$ blasts. In cases with aberrant expression of $\mathrm{CD} 19^{+}, \mathrm{CD} 56^{+}$, or $\mathrm{CD}_{14}{ }^{+}$, B cells, natural killer cells, or monocyte counts, respectively, could not be quantified.

\section{Generation}

$\mathrm{DC}_{\text {leu}}$-containing $\mathrm{DC}$ were generated from $\mathrm{AML}$ patients' MNC obtained in active stages of the disease (first diagnosis, persisting disease, relapse before or after SCT) and afterward used for mixed lymphocyte cultures (MLC) using stem cell donors' or patients' autologous T cells or T cells after SCT (Table 1).

Thawn MNCs were pipetted in 12-well tissue culture plates in $1 \mathrm{~mL}$ Xvivo 15 (Bio Whittaker Europe, Verviers, Belgium) FCS-free medium. DCs were generated from blood samples according to a refined strategy culturing cells in a minimalized assay with 3 DC-generating methods (MCM-Mimic, Picibanil, Ca-Ionophore, Table 2) in parallel, as described by us. ${ }^{31-33}$

All of the substances used for DC generation are approved for human treatment.

For the analysis of a successful generation of DC, cells were quantified by flow cytometry using patient-specific "blast"-staining antibodies (CD33, CD13, CD15, CD65, CD34, and CD117) according to diagnostic reports in combination with DC-staining antibodies (CD1a, CD1b, CD40, CD80, CD83, CD86, and CD206) as described. ${ }^{34}$ We defined DC generation as successful if at least $>10 \%$ DC and $>5 \%$ leukemia-derived DC $\left(\mathrm{DC}_{\text {leu }}\right)$ could be generated in the MNC fraction. ${ }^{32} \mathrm{DC}_{\text {leu }}$ were defined by the coexpression of blast-with DC-markers. The method resulting in the highest DC count was chosen for quantitative generation of DC.

We generated DC successfully in every given case of our 12 patient and 5 healthy proband samples according to procedures already described by members of our group. ${ }^{30,32}$ AML samples presented with on average $20 \% \pm 14 \%$ DC (range, $10 \%-51 \%$ ) and $6 \% \pm 2 \% \mathrm{DC}_{\text {leu }}$ (range, $5 \%-10 \%$ ) after cultivation in selected best DC medium for individual patients. We selected Picibanil, 3 times Ca-Ionophore, and 7 times MCM-mimic.

\section{MLC}

As shown in Table $1 \mathrm{CD}^{+} \mathrm{T}$ cells (later on used as "effector" T cells) were positively selected (Milteney Biotech, Bergisch-Gladbach, Germany, $1 \times 10^{6}$ cells/well) from MNC from patients (autologous $\mathrm{n}=6$ ), from matched stem cell donors $(n=1)$, or from patients in remission or at relapse after stem cell transplantation $(n=5$, Table 1 , right side) and cocultured with "stimulator-cells": irradiated (20 Gy) AML blast-containing MNC $\left[2.5 \times 10^{4}\right.$ MNC (T'MNC')] and in parallel with irradiated $\mathrm{DC}_{\mathrm{leu}}$-containing AML DC $\left[2.5 \times 10^{4}\right.$ DC (T'DC')] in $1 \mathrm{~mL}$ RPMI-1640 medium (Biochrom, Berlin, Germany) containing 15\% human serum (PAA) and IL-2 $50 \mathrm{U} / \mathrm{mL}$ (Proleukin R5, Chiron, Munich, Germany). T-cell stimulation was performed using a cell suspension containing a mixture of blasts-converted DC ( $\left.\mathrm{DC}_{\text {leu }}\right)$, blasts, DC, monocytes, and lymphocytes ('DC'). Total DC counts in the MLC were adjusted to $2.5 \times 10^{4} \mathrm{DC}$ and T-cell counts adjusted to $1 \times 10^{6} /$ well. After 2 -fold restimulation with $2.5 \times 10^{4}$ ' $\mathrm{DC}$ ' or 'MNC', supplementation of IL-2 $(50 \mathrm{U} / \mathrm{mL})$, and half medium exchange on days 3 and 5 , cells were harvested on days 7-8 and the cytotoxicity fluorolysis assay was carried out. DC (generated from 5 healthy monocytes containing MNC) or MNC served as healthy "stimulator cells" for autologous "effector" T cells prepared from these healthy donors, as described. ${ }^{30,32}$

\section{Cell Characterization by Flow Cytometry}

Flow cytometric analysis was carried out using monoclonal mouse antihuman antibodies (moAbs) labeled with fluorescein isothiocyanate (FITC), phycoerythrin (PE), tandem Cy7-PE conjugation (PC7), or allophycocyanin (APC). Antibodies were provided by Immunotech/Beckman Coulter ${ }^{\mathrm{a}}$, Becton Dickinson ${ }^{\mathrm{b}}$, Caltag ${ }^{\mathrm{c}}$, Serotech $^{\mathrm{d}}$, and Invitrogen ${ }^{\mathrm{e}}$. As FITC-conjugated moAbs, we used CD1b ${ }^{\mathrm{b}}$, $\mathrm{CD} 80^{\mathrm{ab}}, \mathrm{CD}^{\mathrm{a}}{ }^{\mathrm{a}}, \mathrm{CD} 86^{\mathrm{c}}, \mathrm{CD}^{\mathrm{a}}, \mathrm{CD} 25^{\mathrm{a}}, \mathrm{CD} 39^{\mathrm{d}}, \mathrm{CD}^{2} \mathrm{RO}^{\mathrm{a}}$,

TABLE 2. DC-differentiating Methods Selected for Individual AML Patients (After Pretesting)

\begin{tabular}{|c|c|c|c|c|c|}
\hline $\begin{array}{l}\text { DC-generating } \\
\text { Method/Medium }\end{array}$ & $\begin{array}{c}\text { DC Differentiation- } \\
\text { stimulating Substances }\end{array}$ & Mode of Action & $\begin{array}{l}\text { Culture } \\
\text { Time (d) }\end{array}$ & References & $\begin{array}{c}\text { DC Method for } \\
\text { Individual Samples }\end{array}$ \\
\hline MCM-Mimic & $\begin{array}{l}\text { GM-CSF, IL-4, TNF } \alpha \text {, } \\
\text { IL-1 } \beta, \text { IL-6, PGE2 }\end{array}$ & $\begin{array}{l}\text { Cytokine-based } \\
\text { DC-differentiation, } \\
\text { PGE2 increases } \\
\text { CCR7-expression and } \\
\text { improves migration }\end{array}$ & $10-14$ & $\begin{array}{l}\text { Kremser } \\
\text { et } \mathrm{al}^{32} \\
\text { Dreyssig } \\
\text { et } \mathrm{al}^{33}\end{array}$ & $\begin{array}{l}\text { m569 (M0) } \\
610 \text { (M4) } \\
748 \text { (M2) } \\
\text { m761 (M1) } \\
853 \text { (M0) } \\
887 \text { (MDS/CMML) } \\
914 \text { (sAML) }\end{array}$ \\
\hline Picibanil & $\begin{array}{l}\text { GM-CSF, TNF } \alpha \text {, lysate } \\
\text { from Streptococcus } \\
\text { pyogenes, PGE2 }\end{array}$ & $\begin{array}{l}\text { Bacterial lysat and PGE2 } \\
\text { stimulate DC } \\
\text { differentiation }\end{array}$ & $7-8$ & $\begin{array}{l}\text { Kremser } \\
\text { et al } \\
\text { Dreyssig } \\
\text { et } \text { al }^{33}\end{array}$ & $\begin{array}{l}824(\mathrm{M} 1 / \mathrm{M} 2) \\
855(\mathrm{M} 4)\end{array}$ \\
\hline Ca-Ionophore & IL-4, A23187 & $\begin{array}{l}\text { Bypass of cytokine-driven } \\
\text { DC differentiation }\end{array}$ & $2-3$ & $\begin{array}{l}\text { Kremser } \\
\text { et } \mathrm{al}^{32} \\
\text { Dreyssig } \\
\text { et } \mathrm{al}^{33}\end{array}$ & $\begin{array}{l}880(\mathrm{M} 4) \\
938 \text { (M4) } \\
948 \text { (M5) }\end{array}$ \\
\hline
\end{tabular}

AML indicates acute myeloid leukemia; CMML, chronic myelomonocytic leukemias; DC, dendritic cells; MDS, myelodysplastic syndromes; sAML, secondary AML. 
and $\mathrm{CD} 122^{\mathrm{d}}$. As PE-conjugated moABs, we used CD80a $\mathrm{CD} 3^{\mathrm{a}}, \mathrm{CD} 86^{\mathrm{bc}}, \mathrm{CD} 206^{\mathrm{a}}, \mathrm{CD} 4^{\mathrm{a}}, \mathrm{CD} 8^{\mathrm{b}}, \mathrm{CD} 73^{\mathrm{b}}, \mathrm{CD} 12^{\mathrm{a}}$, and CD152a . As PC7-conjugated moABs, we used CD1a ${ }^{a}$, $\mathrm{CD} 40^{\mathrm{c}}, \mathrm{CD}^{\mathrm{a}}, \mathrm{CD}^{\mathrm{a}}, \mathrm{CCR} 7^{\mathrm{b}}$, and $7 \mathrm{AAD} . \mathrm{CD}^{3} 4^{\mathrm{ac}}$, $\mathrm{CD} 117^{\mathrm{a}}, \mathrm{CD} 33^{\mathrm{a}}, \mathrm{CD} 1 \mathrm{a}^{\mathrm{a}}, \mathrm{CD} 40^{\mathrm{c}}, \mathrm{CD} 206^{\mathrm{a}} \mathrm{CD}^{\mathrm{a}}, \mathrm{CD} 8^{\mathrm{b}}$, $\mathrm{CD} 25^{\mathrm{e}}, \mathrm{CD} 45 \mathrm{RO}^{\mathrm{e}}, \mathrm{CD} 69^{\mathrm{b}}$, and $\mathrm{CD}^{2} 1^{\mathrm{b}}$ were used as APCconjugated moAbs.

For analysis and quantification of lymphocytes, monocytes, and leukemic blasts before culture, the total MNC fraction was gated. Proportions of positive events in defined gates compared with the isotype controls were calculated using the Cell Quest software. Quantification and characterization of $\mathrm{DC}$ and $\mathrm{DC}_{\text {leu }}$ were performed by flow cytometry according to our gating strategy already described by former groups. ${ }^{30-34}$ To quantify and characterize the several T-cell subpopulations, we defined a "lympho-gate" surrounding lymphocytes and monocytes. T-cell subgroups were defined by antigen coexpression before and after 'MNC' or 'DC' stimulation as shown in Table 3. Flow cytometric analyses were carried out on days $0,1,3,5$, and 7 followed by a functional cytotoxic fluorolysis assay on days 7 or 8 as described below.

\section{Cytotoxicity Fluorolysis Assay}

The lytic activity of effector $\mathrm{T}$ cells was measured by a fluorolysis assay by counting viable blast target cells, labeled with specific fluorochrome antibodies, before and after effector cell contact as described. ${ }^{30}$ 'DC'-stimulated or 'MNC'-stimulated $\mathrm{T}$ cells from healthy matched donors $(\mathrm{n}=1)$, from AML patients (autologous $\mathrm{n}=5$ ), or from AML patients after SCT (after SCT $\mathrm{n}=5$ ) and unstimulated $\mathrm{T}$ cells were cocultured with thawn blasts as target cells for 4 or 24 hours, as described. Before culture, blasttarget cells were stained for 15 minutes with 2 FITC and/or PE-conjugated blast-specific antibodies and subsequently cocultured with effector cells. As a control, target and effector cells were cultured separately and mingled with $\mathrm{T}$ cells shortly before FACS analysis. To evaluate the amount of viable $\left(7 \mathrm{AAD}^{-}\right)$target cells and to quantify the cell loss after 24 hours of incubation, cells were harvested, washed in phosphate-buffered saline, and resuspended in a FACS flow solution containing 7AAD (BD, Biosciences Pharmingen) and a defined number of fluorospheres beads (Becton Dickinson, BD, Heidelberg, Germany). Viable cells were gated in an $\mathrm{SSC}_{7} \mathrm{AAD}^{-}$gate, and viable cells coexpressing the patient-specific blast phenotype were quantified later by taking into account defined counts of calibration beads as described. Cells were analyzed in a FACS Calibur Flow Cytometer using the CELL Quest software (Becton Dickinson). The percentage of lysis was defined as the difference between proportions of viable blasts before and after effector cell contact. Results are given in Table 1 .

\section{Statistical Methods}

Means, SDs, and results with the 2-tailed $t$ test were evaluated with a personal computer using Excel2007 (Microsoft). Differences were considered as significant if the $P$-value was $<0.05$

\section{RESULTS}

We wanted to enlighten the development, activation, proliferation, and differentiation of $\mathrm{T}$ cells before and especially after ' $\mathrm{MNC}$ ' or 'DC' stimulation in AML patients and healthy probands with special focus on the role of regulatory $\mathrm{T}$ cells and $\mathrm{T}_{\text {reg }}$ subtypes (as given in Table 3 ) in the mediation of antileukemic activities of ' $\mathrm{MNC}$ 'stimulated, 'DC'-stimulated, or unstimulated T cells.

\section{'DC' Stimulation Leads to Alteration in T-cell Profiles}

We and others have already demonstrated the variable blast-lytical outcome of T cells after 'MNC' or 'DC' stimulation. ${ }^{30} \mathrm{We}$ compared the expression of several T-cell markers (as listed in Table 2) on unstimulated $\mathrm{T}$ cells (day 0 ) and after stimulation (day 7) in MLC. To prevent any unwanted 'MNC' or 'DC' stimulation of T cells, measurements on day 0 were carried out "on ice."

\begin{tabular}{|c|c|c|}
\hline Names of T-cell Subgroups & Short Text Form & Surface Marker Combination \\
\hline $\mathrm{CD}^{+} \mathrm{T}$ cells & $\mathrm{CD}^{+}{ }^{+} \mathrm{T}$ cells & $\mathrm{CD}^{+}$ \\
\hline $\mathrm{CD}^{+}{ }^{+}$-expressing $\mathrm{T}$ cells & $\mathrm{CD}^{+}{ }^{+} \mathrm{T}$ cells & $\mathrm{CD} 4^{+} \mathrm{CD}^{+}$ \\
\hline $\mathrm{CD}^{+}$-expressing $\mathrm{T}$ cells & $\mathrm{CD}^{+}{ }^{+} \mathrm{T}$ cells & $\mathrm{CD}^{+} \mathrm{CD}^{+}$ \\
\hline Regulatory $\mathrm{T}$ cells & $\mathrm{T}_{\mathrm{reg}}$ & \\
\hline IL-2-R ${ }^{+}$IL-7- $\mathrm{R}^{\text {low }}$-expressing $\mathrm{CD}^{+} \mathrm{T}$ cells & $\mathrm{CD}^{+}{ }^{+} \mathrm{T}_{\text {reg }}$ & $\mathrm{CD} 8^{+} \mathrm{CD} 25^{++} \mathrm{CD} 127^{\text {low }}$ \\
\hline IL-2-R ${ }^{+}$IL-7- ${ }^{\text {low }}$-expressing CD4 ${ }^{+} \mathrm{T}$ cells & $\mathrm{CD}^{+} \mathrm{T}_{\text {reg }}$ & $\mathrm{CD} 4^{+} \mathrm{CD} 25^{++} \mathrm{CD} 127^{\text {low }}$ \\
\hline IL-2-R ${ }^{+}$IL- $^{-}-\mathrm{R}^{\text {low }} \mathrm{CCR}^{-}{ }^{-} \mathrm{CD} 45 \mathrm{RO}^{-} \mathrm{T}$ cells & $\mathrm{T}_{\text {naive reg }}$ & 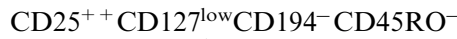 \\
\hline $\mathrm{IL}^{-2}-\mathrm{R}^{+} \mathrm{IL}-7-\mathrm{R}^{\text {low }} \mathrm{CCR}^{-}{ }^{-} \mathrm{CD} 45 \mathrm{RO}^{+} \mathrm{T}$ cells & $\mathrm{T}_{\text {eff } / \mathrm{em} \mathrm{reg}}$ & $\mathrm{CD} 25^{++} \mathrm{CD} 127^{\text {low }} \mathrm{CCR} 7^{-} \mathrm{CD} 45 \mathrm{RO}^{+}$ \\
\hline IL-2-R ${ }^{+} \mathrm{IL}^{-7-\mathrm{R}^{\text {low }} \mathrm{CCR}^{+}{ }^{+} \mathrm{CD} 45 \mathrm{RO}^{+} \mathrm{T} \text { cells }}$ & $\mathrm{T}_{\mathrm{cm} \text { reg }}$ & $\mathrm{CD} 25^{++} \mathrm{CD} 127^{\text {low }} \mathrm{CCR}^{+}{ }^{+} \mathrm{CD} 45 \mathrm{RO}^{+}$ \\
\hline $\begin{array}{l}\text { IL-2-R }{ }^{+} \text {IL7-R }{ }^{\text {low }} \text { Ecto-Apyrase, Ntpd-ase } \\
\text { 1-expressing CD } 4^{+} \mathrm{T} \text { cells }\end{array}$ & $\mathrm{CD} 39^{+} \mathrm{T}_{\text {reg }}$ & $\mathrm{CD} 39^{+} \mathrm{CD} 25^{++} \mathrm{CD} 127^{\text {low }} \mathrm{CD} 4^{+}$ \\
\hline IL7-R ${ }^{\text {low }}$ Ecto- $5^{\prime}$-Nucleotidase-expressing $\mathrm{T}$ cells & $\mathrm{CD} 3^{+} \mathrm{T}_{\mathrm{reg}}$ & $\mathrm{CD}_{73^{+}}$ \\
\hline CTLA- $4^{+} \mathrm{T}$ cells & $\mathrm{CD} 152^{+} \mathrm{T}_{\mathrm{reg}}$ & $\mathrm{CD}_{152}{ }^{+} \mathrm{CD}^{+}+$ \\
\hline \multicolumn{3}{|l|}{ Activated $\mathrm{T}$ cells } \\
\hline IL-2- $\mathrm{R}^{+} \mathrm{T}$ cells & $\mathrm{CD} 122^{+} \mathrm{T}$ cells & $\mathrm{CD}_{122}{ }^{+} \mathrm{CD}^{+}$ \\
\hline CD $40 \mathrm{~L}^{+} \mathrm{T}$ cells & $\mathrm{CD} 154^{+} \mathrm{T}$ cells & $\mathrm{CD} 152^{+} \mathrm{CD}^{+}$ \\
\hline $\mathrm{IL}_{-2}-\mathrm{R}^{+} \mathrm{CD} 4^{+} \mathrm{T}$ cells & $\mathrm{CD} 25^{+} \mathrm{CD} 4^{+} \mathrm{T}$ cells & $\mathrm{CD} 25^{+} \mathrm{CD} 4^{+}$ \\
\hline IL-2-R ${ }^{+} \mathrm{CD} 8^{+} \mathrm{T}$ cells & $\mathrm{CD} 25^{+} \mathrm{CD} 8^{+} \mathrm{T}$ cells & $\mathrm{CD} 25^{+} \mathrm{CD} 8^{+}$ \\
\hline $\mathrm{IL}_{-7}-\mathrm{R}^{+} \mathrm{CD} 4^{+} \mathrm{T}$ cells & $\mathrm{CD} 127^{+} \mathrm{CD} 4^{+} \mathrm{T}$ cells & $\mathrm{CD} 127^{+} \mathrm{CD}^{+}+$ \\
\hline $\mathrm{IL}_{-}-\mathrm{R}^{+} \mathrm{CD} 8^{+} \mathrm{T}$ cells & $\mathrm{CD} 127^{+} \mathrm{CD}^{+}{ }^{+} \mathrm{T}$ cells & $\mathrm{CD} 127^{+} \mathrm{CD}^{+}$ \\
\hline \multicolumn{3}{|l|}{ Proliferating $\mathrm{T}$ cells } \\
\hline Type II C-type lectin ${ }^{+} \mathrm{T}$ cells & $\mathrm{CD} 9^{+} \mathrm{T}$ cells & $\mathrm{CD}_{6} 9^{+} \mathrm{CD}^{+}{ }^{+}$ \\
\hline Transferrin- $\mathrm{R}^{+} \mathrm{T}$ cells & $\mathrm{CD} 71^{+} \mathrm{T}$ cells & $\mathrm{CD}_{71}{ }^{+} \mathrm{CD}^{+}$ \\
\hline
\end{tabular}




\section{Profiles of Uncultured T Cells From AML Patients Compared With Healthy Probands}

\section{AML Patients Show Significantly Lower Levels of Both $\mathrm{CD}_{127}{ }^{+} \mathrm{CD}^{+}$and $\mathrm{CD}_{127}{ }^{+} \mathrm{CD8}^{+}$T Cells Before DC or MNC Stimulation}

We studied the expression of activation and proliferation markers on uncultured T cells from AML patients and from healthy probands. Low amounts of proliferating or activated $\mathrm{T}$ cells $\left(\mathrm{CD}^{+} \mathrm{T}\right.$ cells expressing CD69, CD71, and CD122 or $\mathrm{CD}^{+} / \mathrm{CD}^{+} \mathrm{T}$ cells expressing $\mathrm{CD} 25$ ) were found on unstimulated $\mathrm{T}$ cells $(\mathrm{d} 0)$ in the MLC of healthy donors and AML patients (Fig. 1A). However, healthy probands showed significantly higher levels of $\mathrm{CD} 127^{+} \mathrm{CD}^{+} \quad(93 \% \pm 7 \%$ vs. $65 \% \pm 21 \%)$ and $\mathrm{CD}_{12} 7^{+} \mathrm{CD}^{+}(86 \% \pm 10 \%$ vs. $52 \% \pm$ $17 \%)$ T cells compared with AML patients $(P<0.005$, Fig. 1A).

In summary, this means that low amounts of proliferating $\mathrm{T}$ cells were found in unstimulated $\mathrm{T}$ cells from healthy donors or AML patients, but significantly higher proportions of $\mathrm{CD}^{+} / \mathrm{CD}^{+} \mathrm{T}$ cells expressed $\mathrm{CD} 127$ in healthy compared with AML donors.

\section{AML Patients Present With Significantly Higher Levels of Several $T_{\text {reg }}$ Subgroups Before ' $D C$ ' or 'MNC' Stimulation}

We compared the expression of common regulatory cell markers on uncultured T cells of AML patients and healthy probands.

Comparable amounts of unstimulated (d0) $\mathrm{CD}^{+}$ T cells expressing CD152 or CD $4^{+}$T cells expressing CD39 (with or without CD25/CD127 expression) were found in healthy probands or AML patients (Fig. 1B, upper part). However, healthy probands showed significantly lower amounts of $\mathrm{CD}^{+} \mathrm{T}_{\text {reg }}$ in $\mathrm{CD}^{+} \mathrm{T}$ cells $(11 \% \pm 5 \%$ vs. $29 \% \pm 11 \%, \quad P<0.005) \quad$ or $\mathrm{CD}^{+} \quad \mathrm{T}_{\text {reg }}$ in $\mathrm{CD}^{+}$ T cells $(4 \% \pm 2 \%$ vs. $14 \% \pm 9 \%, P<0.005)$ or $\mathrm{CD} 39^{+}$ cells in MLC fractions $(10 \% \pm 6 \%$ vs. $25 \% \pm 6 \%$, $P<0.005)$ compared with AML patients. In contrast, we found significantly higher amounts of $\mathrm{CD}^{2} 3^{+}$cells in MLC in healthy probands compared with AML patients (33\% $\pm 5 \%$ vs. $19 \% \pm 11 \%, P<0.005$, Fig. $1 \mathrm{~B}$, upper part).

Furthermore we found significantly lower amounts of all $\mathrm{T}_{\text {reg }}$ subsets in unstimulated cell fractions in healthy probands compared with AML patients: $\mathrm{T}_{\text {naive reg }}$ in MLC $(1 \% \pm 1 \%$ vs. $4 \% \pm 4 \%, P<0.05), \mathrm{T}_{\text {naive reg }}$ in $\mathrm{T}_{\text {naive }},(12 \% \pm 17 \%$ vs. $28 \% \pm 17 \%, P<0.05), \mathrm{T}_{\text {eff }} / \mathrm{em}$ reg in MLC $(5 \% \pm 3 \%$ vs. $10 \% \pm 7 \%, \quad P<0.05), \quad \mathrm{T}_{\text {eff/em }}$ reg in $\mathrm{T}_{\text {eff } / \mathrm{em}}(9 \% \pm 7 \%$ vs. $19 \% \pm 9 \%, P<0.005), \mathrm{T}_{\mathrm{cm}}$ reg in $\operatorname{MLC}(1 \% \pm 1 \%$ vs. $4 \% \pm 2 \% P<0.005)$, and $\mathrm{T}_{\mathrm{cm}}$ reg in $\mathrm{T}_{\mathrm{cm}}(17 \% \pm 14 \%$ vs. $31 \% \pm 13 \%, P<0.05$ ) (Fig. 1B, lower part).

In summary, we found significantly lower frequencies of several $\mathrm{T}_{\text {reg }}$ subgroups in unstimulated $\mathrm{T}$ cells in healthy probands compared with AML patients.

\section{Profiles of 'MNC'-stimulated Versus 'DC'- stimulated T Cells After 7 Days of Culture in MLC in Cases With AML or in Healthy Probands}

AML Patients Show Significantly Lower Levels of $\mathrm{CD} 127^{+} \mathrm{CD}^{+}$and $\mathrm{CD}^{2} 7^{+} \mathrm{CD8}^{+} \mathrm{T}$ Cells After 'DC' or 'MNC' Stimulation Compared With Healthy Probands

We compared the expression of common regulatory cell markers on $\mathrm{T}$ cells from AML patients and healthy probands after stimulation with 'MNC' or 'DC', respectively (Fig. 2A).
In the AML patients' cohort, after 7 days with 'DC' stimulation, comparable, although lower, amounts of $\mathrm{CD}^{+} \mathrm{T}$ cells coexpressed $\mathrm{CD} 69^{+}, \mathrm{CD} 71^{+}$, and $\mathrm{CD} 122^{+}$compared with healthy donors. Moreover, comparable amounts of both $\mathrm{CD}^{+}$and $\mathrm{CD}^{+} \mathrm{T}$ cells coexpressing CD25 were found (Fig. 2A). However, compared with AML patients, healthy probands showed significantly higher levels of $\mathrm{CD}_{12} 7^{+} \mathrm{CD}^{+}(78 \% \pm 20 \%$ vs. $26 \% \pm 19 \%, P<0.05)$ and $\mathrm{CD} 127^{+} \mathrm{CD}^{+}$T cells on day $7(62 \% \pm 27 \%$ vs. $17 \% \pm 14 \%$, $P<0.05$, Fig. 2A). After 7 days of 'MNC' stimulation, similar expression patterns could be observed (data not shown).

\section{AML Patients Present With Significantly}

Higher Levels of $T_{\mathrm{cm}}$ reg and $\mathrm{T}_{\mathrm{eff} / \mathrm{em} \text { reg }}$ After ' $\mathrm{DC}$ ' or 'MNC' Stimulation Compared With Healthy Probands

We compared the expression of various regulatory cell markers on $\mathrm{T}$ cells from AML patients and healthy probands after stimulation with 'MNC' or 'DC', respectively (Fig. 2B). Concerning the expression of $\mathrm{CD}_{73}^{+}, \mathrm{CD} 152^{+}$, $\mathrm{CD} 39^{+} \mathrm{CD} 4^{+}$, and $\mathrm{CD} 39^{+} \mathrm{CD} 25^{++} \mathrm{CD} 127^{\text {low }} \mathrm{T}$ cells, no significant differences between AML patients and healthy probands could be observed after 7 days with 'DC' stimulation (Fig. 2B). Tendentially, healthy probands showed lower amounts of $\mathrm{CD}^{+} \mathrm{T}_{\text {reg }}$ (referred to $\mathrm{CD}^{+}$cells) and $\mathrm{CD} 8^{+} \mathrm{T}_{\text {reg }}$ (referred to $\mathrm{CD}^{+}$cells) compared with AML patients $(P<0.1) \quad$ (Fig. 2B, upper part). However, compared with AML samples, healthy probands presented with significantly lower amounts of $\mathrm{T}_{\mathrm{cm}}$ reg $(26 \% \pm 8 \%$ vs. $58 \% \pm$ $21 \%, P<0.005)$ and $\mathrm{T}_{\mathrm{eff} / \mathrm{em}}(33 \% \pm 14 \%$ vs. $59 \% \pm$ $16 \%, P<0.05)$ and tendentially lower amounts of $\mathrm{T}_{\text {naive reg }}$ $(53 \% \pm 31 \%$ vs. $78 \% \pm 22 \%, P \leq 0.1$, Fig. $2 \mathrm{~B}$, lower part $)$ after 7 days of 'DC' stimulation. Values after 7 days of 'MNC' stimulation in AML patients and healthy probands were comparable to values after 'DC' stimulation (data not shown).

In summary, we still found significantly higher levels of $T_{\text {reg }}$ subtypes in AML patients compared with healthy probands on day 7 .

\section{Kinetic Profiles of Surface Markers on T Cells in the Time Course of 'DC' or 'MNC' Stimulation (Day 0-7)}

We examined the kinetic development of surface marker profiles, performed measurements on days $0,1,3,5$, and 7 , and compared statistical profiles of day 0 and 7 (Fig. 3).

\section{Expression Profiles of Activation and Proliferation Are} Comparable in AML Patients and Healthy Probands

Proportions of $\mathrm{CD} 25^{+} \mathrm{T}$ cells stayed rather constant during 'DC' stimulation between day 0 and day 7 in both groups (Fig. 3A). In general (with the exception of CD127), $\mathrm{T}$ cells from healthy probands showed a similar kinetic development during 'DC' stimulation compared with AML patients. As shown in Fig. 3A, the kinetics of healthy probands showed no significant decrease in $\mathrm{CD} 127^{+} \mathrm{T}$ cells, whereas the expression on $\mathrm{CD}^{+} \mathrm{T}$ cells decreased significantly from $63 \% \pm 23 \%$ to $26 \% \pm 19 \%$ in AML patients $(P<0.005)$ between day 0 and 7 . We could demonstrate a significant increase in $\mathrm{CD}^{+} 9^{+} \mathrm{T}$ cells in AML patients $(2 \% \pm 2 \%$ to $18 \% \pm 20 \%, P<0.05)$ and healthy probands $(6 \% \pm 7 \%$ to $21 \% \pm 9 \%, P<0.05)$ between day 0 and 7 of ' $\mathrm{DC}$ ' stimulation $(P<0.05$, Fig. $3 \mathrm{~A})$. CD $71^{+}$T cells of AML patients $(8 \% \pm 9 \%$ to $28 \% \pm 19 \%, P<0.05)$ and healthy probands $(15 \% \pm 15 \%$ to $39 \% \pm 22 \%, P<0.1)$ and $\mathrm{CD} 122^{+} \mathrm{T}$ cells of AML patients $(4 \% \pm 2 \%$ to $12 \% \pm 9 \%, P<0.05)$ and healthy probands $(4 \% \pm 2 \%$ to $12 \% \pm 8 \%, P<0.1)$ showed a significant continuous increase, reaching high values on days 3-5. 
A activation and proliferation

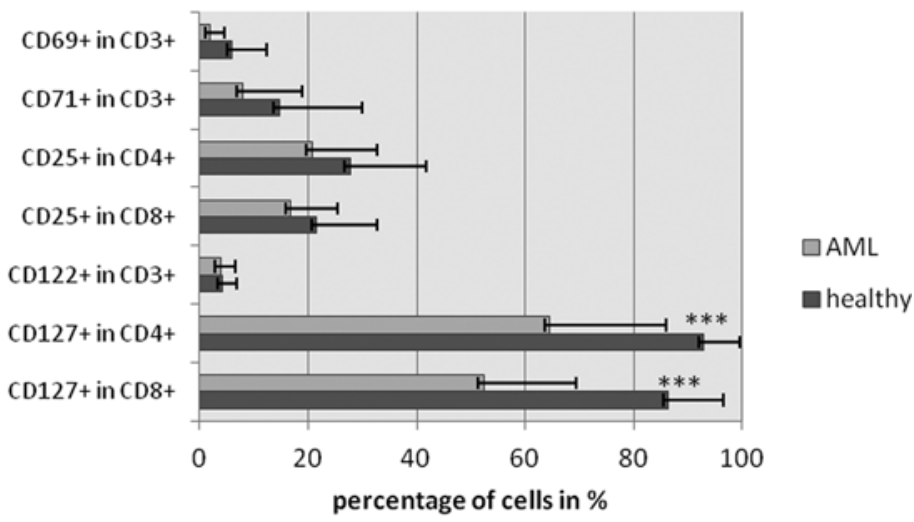

$B$ regulation
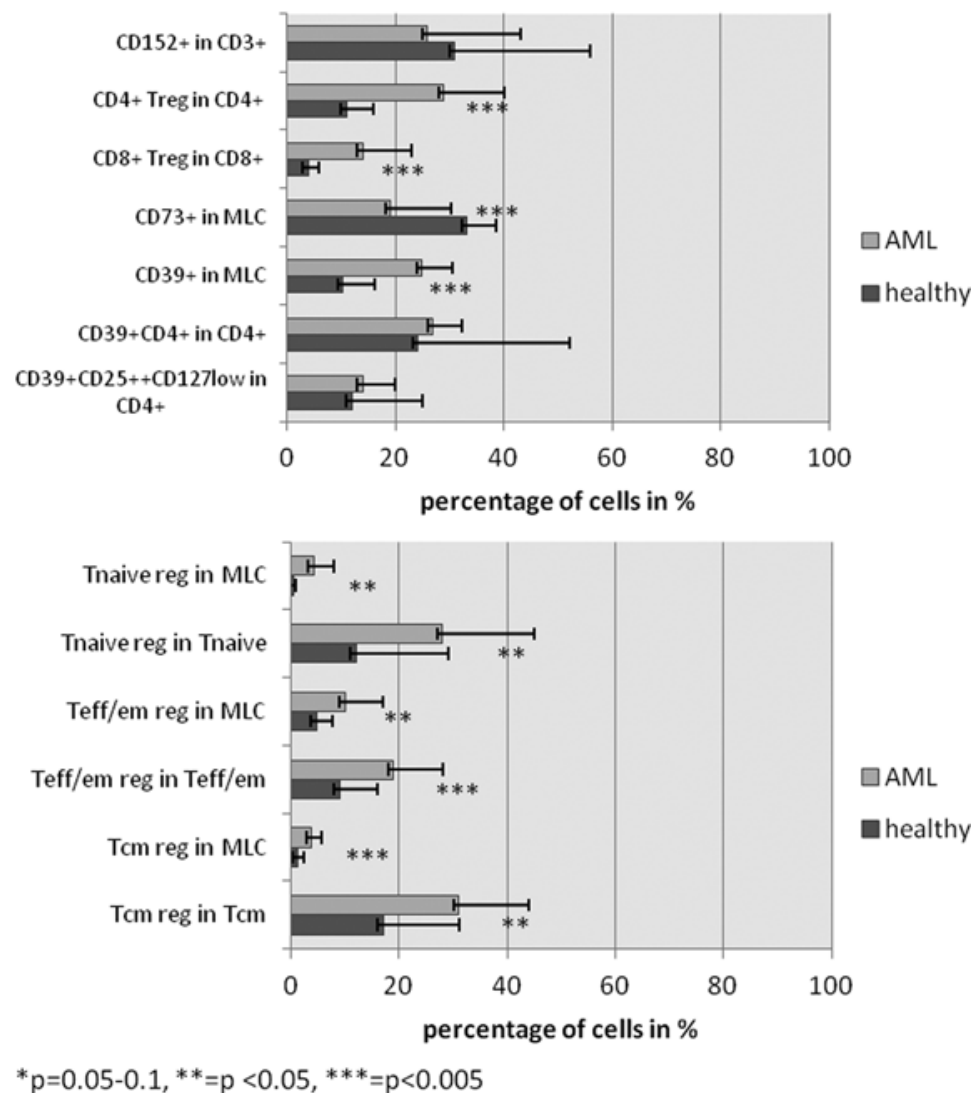

FIGURE 1. Profiles of uncultured T cells from AML patients versus healthy probands on day 0 . Unstimulated T cells before MLC with 'DC' or 'MNC' of AML or healthy samples were stained with different fluorochrome-labeled antibodies, and subpopulations characterizing activation and proliferation $(A)$ or regulation $(B)$ were specifically gated and quantified. AML indicates acute myeloid leukemia; DC, dendritic cells; MLC, mixed lymphocyte cultures; MNC, mononuclear cells.

During stimulation with 'MNC', we could demonstrate an analogous kinetic development as with 'DC' stimulations in healthy and AML samples (data not shown).

In summary, we could show that after 7 days of stimulation with 'DC' or 'MNC', all 17 MLC presented with an increase in immunologic activation markers. Compared with day 0 , AML patients and healthy probands showed a significant upregulation of $\mathrm{CD} 69^{+}, \mathrm{CD} 71^{+}$, and $\mathrm{CD} 122^{+} \mathrm{T}$ cells and a significant downregulation of
$\mathrm{CD} 127^{+} \mathrm{T}$ cells (only in AML) after ' $\mathrm{DC}$ ' stimulation and after 'MNC' stimulation (data not shown).

\section{AML Patients and Healthy Probands Show a Continuous Increase in $\mathbf{T}_{\text {reg }}$ Subgroups}

Similarly, no significant changes in the proportion of $\mathrm{CD} 152^{+} \mathrm{T}$ cells between $\mathrm{d} 0$ and $\mathrm{d} 7$ were seen in AML patients and healthy probands (Fig. 3B). A significant increase in the proportion of T-cell subtypes between $\mathrm{d} 0$ and $\mathrm{d} 7$ was found in 


\section{A activation and proliferation}

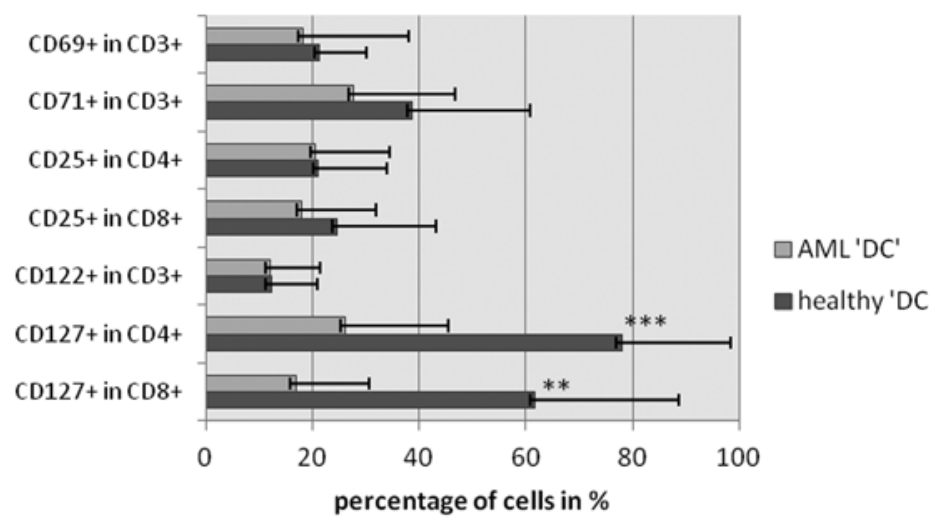

B regulation

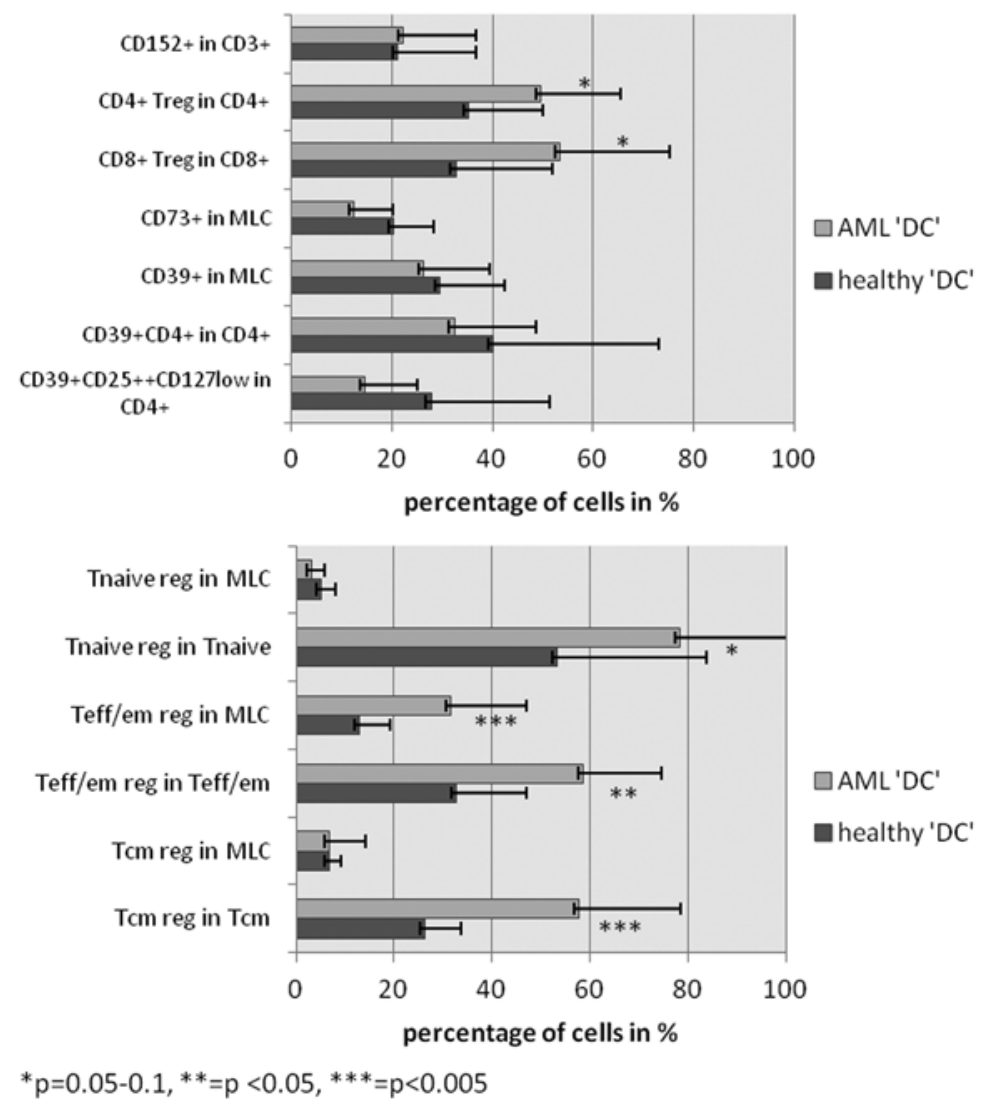

FIGURE 2. Profiles of 'DC'-stimulated T cells from AML patients versus healthy probands on day 7. T cells after MLC with 'DC' of AML or healthy samples were stained with different fluorochrome-labeled antibodies, and subpopulations characterizing activation and proliferation (A) or regulation (B) were specifically gated and quantified. AML indicates acute myeloid leukemia; DC, dendritic cells; MLC, mixed lymphocyte cultures.

AML patients and in healthy probands for $\mathrm{T}_{\text {naive }}$ reg $(\mathrm{AML}$ : $32 \% \pm 20 \%$ to $78 \% \pm 22 \%, P<0.005$; healthy: $13 \% \pm 22 \%$ to $53 \% \pm 31 \%, P<0.05$ ), $\mathrm{T}_{\mathrm{cm}}$ (AML: $35 \% \pm 14 \%$ to $58 \% \pm 21 \%, P<0.05$; healthy: $18 \% \pm 17 \%$ to $26 \% \pm 8 \%$, $P<0.1), \mathrm{T}_{\text {eff } / \mathrm{em}}$ reg $($ AML: $20 \% \pm 10 \%$ to $59 \% \pm 16 \%$, $P<0.005$; healthy: $11 \% \pm 8 \%$ to $33 \% \pm 14 \%, P<0.05$ ), $\mathrm{CD}^{+} \mathrm{T}_{\text {reg }}$ (AML: $15 \% \pm 9 \%$ to $53 \% \pm 22 \%, P<0.005$; healthy: $4 \% \pm 2 \%$ to $33 \% \pm 19 \%, P<0.05)$, and $\mathrm{CD}^{+} \mathrm{T}_{\text {reg }}$ (AML: $31 \% \pm 11 \%$ to $50 \% \pm 16 \%, P<0.005$; healthy:
$12 \% \pm 6 \%$ to $35 \% \pm 15 \%, \quad P<0.05)$. Regarding the ectoenzymes $\mathrm{CD} 9^{+}$and $\mathrm{CD}^{+} 3^{+}$, we could detect a continuous and tendentially significant decrease in $\mathrm{CD} 73^{+}$cells in AML patients and a significant decrease in healthy probands (AML: $19 \% \pm 11 \%$ to $13 \% \pm 08 \%, \quad P<0.1$; healthy: $33 \% \pm 5 \%$ to $20 \% \pm 8 \%, \quad P<0.05) . \quad$ CD $39^{+}$cells, $\mathrm{CD} 39^{+} \mathrm{CD} 4^{+}$, or $\mathrm{CD} 39^{+} \mathrm{CD} 127^{\text {low }} \mathrm{CD} 25^{++} \mathrm{CD} 4^{+}$in $\mathrm{CD} 4^{+}$ $\mathrm{T}$ cells showed no significant increase in $\mathrm{AML}$ patients. However, as shown in Fig. 3B, in healthy probands, we found 
A

activation and proliferation

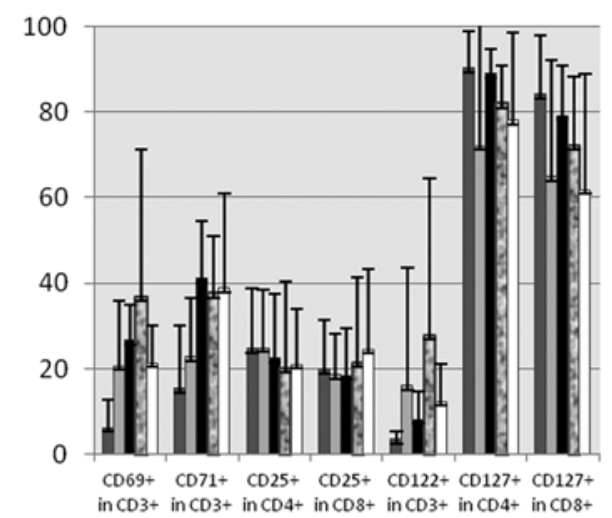

B regulation

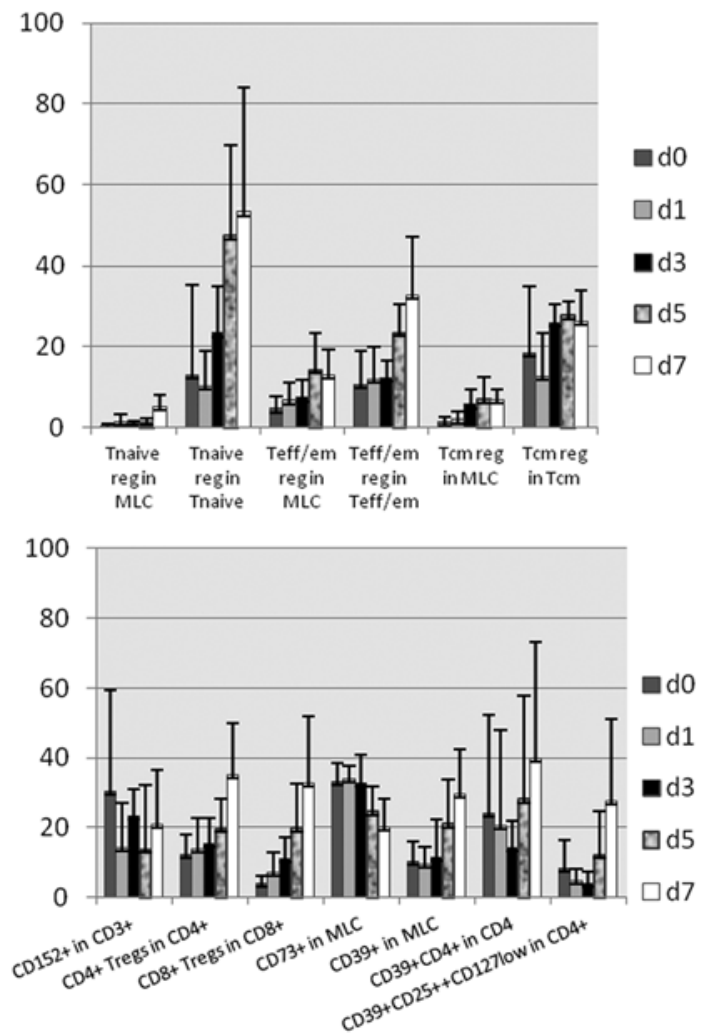

AML
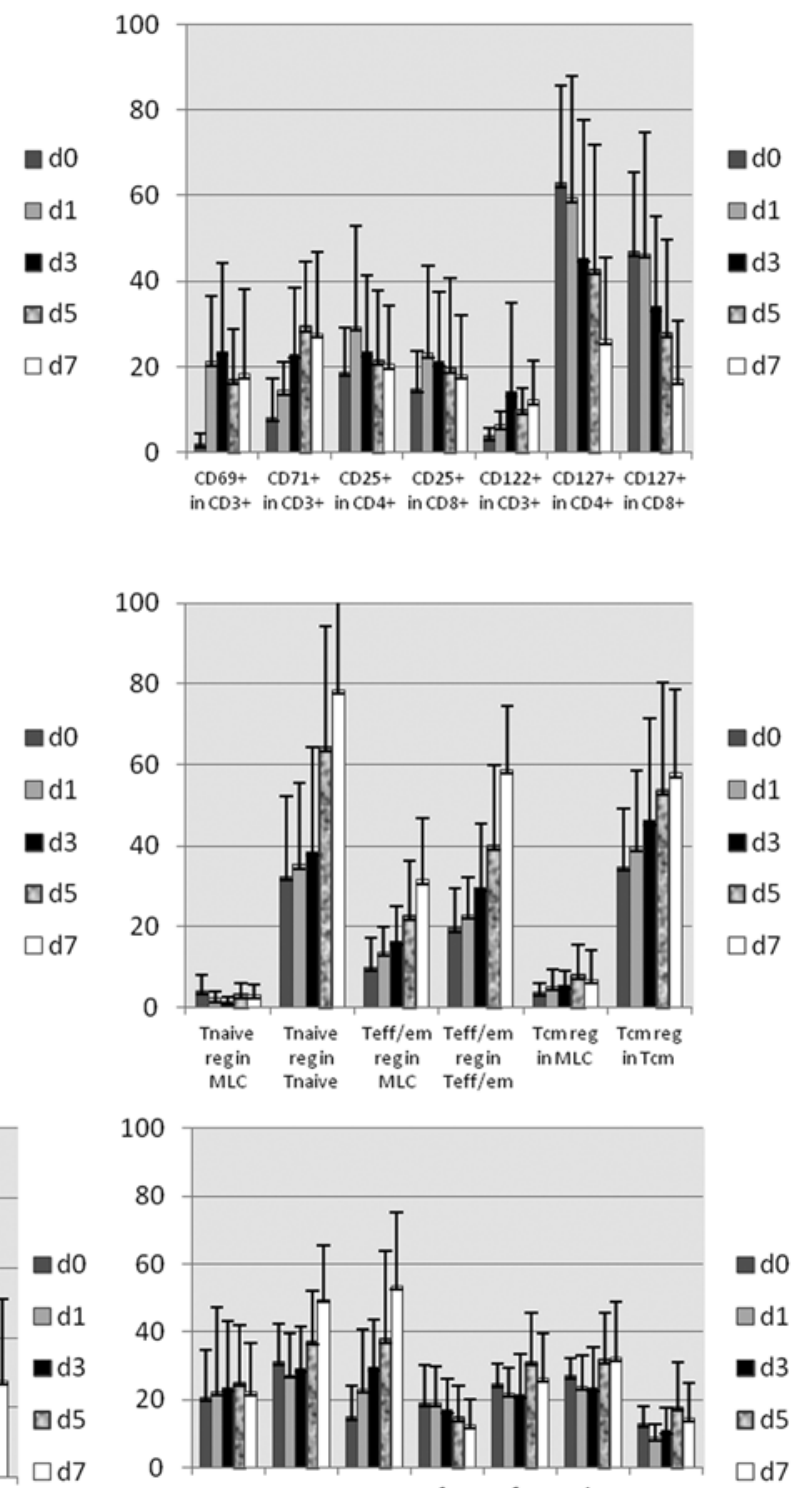

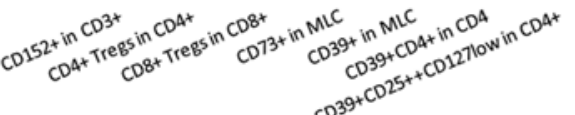

FIGURE 3. Kinetic profiles of surface markers on $T$ cells from AML patients versus healthy probands (in the time course of 'DC' stimulation). Expression profiles of activation and proliferation markers (A) and regulation markers (B) in the course of 'DC' stimulation in healthy (left side) or AML samples (right side) after specific gating of T-cell subtypes are given. AML indicates acute myeloid leukemia; DC, dendritic cells.

a significant and continuous increase in $\mathrm{CD} 39^{+}$cells $(10 \% \pm 6 \%$ to $29 \% \pm 13 \%, P<0.05)$ and $\mathrm{CD} 39^{+} \mathrm{CD} 25^{++} \mathrm{CD} 127^{\text {low }} \mathrm{CD} 4^{+}$ cells $(8 \% \pm 8 \%$ to $28 \% \pm 23 \%, P<0.1)$.

After ' $M N C$ ' stimulation, we could demonstrate an analogous kinetic development (data not shown).

In summary, all subtypes of $\mathrm{T}_{\text {reg }}$ increased significantly after 'DC' or 'MNC' stimulation among AML patients and healthy probands. In AML patients, CD $39^{+} \mathrm{T}_{\text {reg }}$ showed no increase after 7 days of ' $\mathrm{DC}$ ' or 'MNC' stimulation, whereas a tendentially significant increase in $\mathrm{CD} 39^{+} \mathrm{T}_{\text {reg }}$ and a significant increase in $\mathrm{CD} 39^{+}$cells was observed after 'DC' stimulation in healthy probands. We could not detect any significant differences in the pattern of regulatory T cells after 'DC' or 'MNC' stimulation in AML patients and in healthy probands.

Correlation of T-cell Expression Profiles With the Antileukemic Function of 'MNC'-stimulated, 'DC'stimulated, or Unstimulated T Cells in AML Cases

We have already demonstrated that stimulation with $\mathrm{DC}_{\text {leu }}$ improves the antileukemic function of $\mathrm{T}$ cells. Thus, 
we wanted to examine the potential differences of surface marker expression concerning the activation and regulation of $\mathrm{T}$ cells in the context of the antileukemic function of 'DC'-stimulated/'MNC'-stimulated T cells. We subdivided our cases into those that gained lytic activity ("lysis") and those that were not able to lyse blasts ("nonlysis") after 'DC' or 'MNC' stimulation and compared the surface marker profiles regarding the expression of activation, proliferation, and regulation markers on "MNC-stimulated," "DC-stimulated," or unstimulated T cells.

Functional assays showed that 'MNC' stimulation induced antileukemic cytotoxicity in 4 of 11 cases $(36 \%)$ compared with 7 of 11 cases (64\%) after 'DC' stimulation. Unstimulated $\mathrm{T}$ cells showed lytic activity in 5 of 10 cases $(50 \%)$. Unstimulated $\mathrm{T}$ cells showed an average lytic efficiency of $60 \%$ of blasts (range, 30\%-93\%), 'MNC'-stimulated T cells of $41 \%$ (range, $9 \%-80 \%$ ), and 'DC'-stimulated $\mathrm{T}$ cells of $62 \%$ (range, $12 \%-85 \%$ ) of blasts. Cases with lysis after 'DC' stimulation consisted of T cells after SCT $(n=4)$ and autologous T cells $(n=3)$. Cases with lysis after 'MNC' stimulation were $\mathrm{T}$ cells from patients after $\mathrm{SCT}(\mathrm{n}=3)$ and in autologous $\mathrm{T}$ cells in 1 case. T-cell sources of cases with lysis of unstimulated T cells were T cells after SCT $(n=4)$ and in 1 case autologous $\mathrm{T}$ cells. Results of antileukemic activity in individual cases are given in Table 1 (right side).

\section{T-cell Profiles of T Cells Before Stimulation With 'DC' or 'MNC' in AML Cases}

\section{Expression Profiles of Activation and Proliferation Markers on T Cells Before 'DC' or 'MNC' Stimulation in Lysis and Nonlysis Groups of AML Cases Do Not Differ}

On day 0 before ' $D C$ ' stimulation, we found no significant differences between the lytically active and nonactive groups regarding the expression profiles of activation and proliferation markers (Fig. 4A, left side).

\section{Tendentially Lower Proportions of $\mathrm{CD8}^{+} \mathrm{T}_{\mathrm{reg}}$ in the Lysis Group Before 'DC' But Not Before 'MNC' Stimulation}

On day 0 before 'DC' stimulation, we found no significant differences between the lytically active and nonactive groups regarding the expression profiles of $\mathrm{CD} 152^{+}, \mathrm{CD} 4^{+}$ $\mathrm{T}_{\text {reg, }}, \quad \mathrm{CD} 39^{+}, \quad \mathrm{CD} 73^{+}, \quad \mathrm{CD} 39^{+} \mathrm{CD} 4^{+}, \quad \mathrm{CD} 39^{+} \mathrm{CD} 25^{++}$ $\mathrm{CD} 127^{\text {low }}, \mathrm{T}_{\text {naive reg, }}, \mathrm{T}_{\text {eff//m reg, }}$, and $\mathrm{T}_{\mathrm{cm} \text { reg }}$ (Fig. $4 \mathrm{~B}$, left side). However, we found tendentially lower proportions of $\mathrm{CD} 8^{+}$ $\mathrm{T}_{\text {reg }}$ (referred to $\mathrm{CD} 8^{+}$cells) before 'DC' stimulation in the later-on lysis group compared with the nonlysis group $(10 \% \pm 3 \%$ vs. $23 \% \pm 12 \% P \leq 0.1 ;$ Fig. $4 \mathrm{~B}$, left side $)$.

Before ' $M N C$ ' stimulation, we could not detect any significant differences in the levels of any regulatory subgroups between the later on lysis and nonlysis groups (data not shown).

\section{T-cell Profiles After 'MNC' or 'DC' Stimulation in AML Cases}

Expression Profiles of Activation and Proliferation Markers Do Not Show Significant Differences After 'DC' or 'MNC' Stimulation in AML Cases

No significant differences in proportions of activated $\mathrm{T}$ cells (positive for $\mathrm{CD} 69^{+}, \mathrm{C} 71^{+}, \mathrm{CD} 25^{+}, \mathrm{CD} 122^{+}$, and $\mathrm{CD} 127^{+}$) were found between the lytically active and nonactive groups after 'DC' stimulation (Fig.4A, right side).
The Lysis Group Presents With Significantly Lower Amounts of $\mathrm{CD8}^{+} \mathrm{T}_{\text {reg }}$ and $\mathrm{T}_{\text {eff/em reg }}$ After ' $\mathrm{DC}$ ' But Not After 'MNC' Stimulation in AML Cases

No significant differences in proportions of regulatory T-cell subtypes were found in proportions of the following markers in the lytically active compared with the nonactive group after DC stimulation (Fig. 4A, right side): $\mathrm{CD} 152^{+}$ $\mathrm{T}$ cells, $\mathrm{CD}^{+} \mathrm{T}_{\text {reg, }}, \mathrm{CD}_{3} 3^{+}, \mathrm{CD} 39^{+}$, or $\mathrm{CD} 39^{+} \mathrm{CD} 25^{++}$ $\mathrm{CD} 127^{\text {low }}, \mathrm{T}$ cells, and $\mathrm{T}_{\text {naive reg }}$ and $\mathrm{T}_{\mathrm{cm}}$ reg $\mathrm{T}$ cells. Tendentially, significantly lower proportions of $\mathrm{CD}_{3} 9^{+} \mathrm{CD} 4+$ $\mathrm{T}$ cells (referred to as $\mathrm{CD}^{+}{ }^{+}$cells) were found in cases with lysis than in cases without lysis after DC stimulation $(29 \% \pm$ $14 \%$ compared with $44 \% \pm 13 \%, P \leq 0.1)$. Significantly lower proportions of $\mathrm{CD}^{+} \mathrm{T}_{\text {reg }}$ (referred to as $\mathrm{CD} 8^{+}$cells, $45 \% \pm 15 \%$ compared with $76 \% \pm 13 \%, P<0.05)$ and $\mathrm{T}_{\text {eff } / \mathrm{em} \text { reg }}$ (referred to as $\mathrm{T}_{\text {eff } / \mathrm{em}} ; 49 \% \pm 12 \%$ compared with $75 \% \pm 7 \%, P<0.005$ ) were found in the lysis compared with the nonlysis group after 'DC' stimulation (Fig. 4B, right side). It is interesting to note that these correlations between expression profiles concerning regulatory $\mathrm{T}$ cells and antileukemic functionality were not detectable after 'MNC' stimulation.

In summary, we found that low proportions of $\mathrm{T}_{\text {reg }}$ subpopulations $\left(\mathrm{CD} 8^{+} \mathrm{T}_{\text {reg }}, \mathrm{T}_{\text {eff } / \mathrm{em} \mathrm{reg}}\right.$, and $\left.\mathrm{CD} 39^{+} \mathrm{CD} 4^{+}\right)$ in unstimulated and even more in 'DC'-stimulated cell fractions went along with good antileukemic ex vivo activity (Fig. 4B).

\section{Cut-off Values of $\mathrm{T}_{\text {reg }}$ Subpopulations Contribute to Predict the Antileukemic Reactivity of Unstimulated and Even More of 'DC'-stimulated T Cells in AML Cases}

To gain a better prediction of the antileukemic behavior of 'DC'-stimulated or unstimulated T cells, we subgrouped our cases according to their antileukemic function and evaluated predictive cut-off values. These values could be defined for the following regulatory subgroups (before or after 'DC' stimulation): $\mathrm{CD}^{+} \mathrm{T}_{\text {reg }}$ (referred to as $\mathrm{CD}^{+}$cells), $\mathrm{T}_{\text {eff } / \mathrm{em} \text { reg }}$ (referred to as $\mathrm{T}_{\text {eff/em }}$ ), $\mathrm{T}_{\mathrm{cm}}$ reg (referred to as $\mathrm{T}_{\mathrm{cm}}$ ), and $T_{\text {naive reg }}$ (referred to as $T_{\text {naive }}$, Fig. 5). In detail, we could show that cases with $<60 \%$ of $\mathrm{CD}^{+} \mathrm{T}_{\text {reg }}$ in all $\mathrm{CD}^{+}$cells, those with $<60 \%$ of $\mathrm{T}_{\text {eff } / \mathrm{em} \text { reg }}$ in all $\mathrm{T}_{\text {eff } / \mathrm{em}}$ cells, and those with $<70 \%$ of $\mathrm{T}_{\mathrm{cm} \text { reg }}$ in all $\mathrm{T}_{\mathrm{cm}}$ cells showed an $80 \%-100 \%$ antileukemic T-cell activity. Cases with higher proportions of these regulatory $\mathrm{T}$ cells had a high probability to belong to the nonlytic group (range, $67 \%-100 \%$ ). These cut-off values became more distinctive after 'DC' stimulation compared with unstimulated samples and could not be defined after 'MNC' stimulation. Moreover, we could not define any cut-off values regarding the proportions of the activation or the proliferation markers expressed.

Furthermore, we tried to compare these cellular findings with the patients' clinical outcomes. Five of our 12 patients received immunotherapy, of whom 3 patients did not respond, 1 responded, and 1 died of SCT-related complications. The patient responding to immunotherapy had lower proportions of $\mathrm{CD} 8^{+} \mathrm{T}_{\text {reg }}$ and $\mathrm{T}_{\text {eff/em reg }}$ before stimulation and higher proportions of $\mathrm{T}_{\text {naive reg }}$ before and after $\mathrm{DC}$ stimulation compared with the nonresponders (data not shown).

In summary, our findings show that cases with an antileukemic function presented in general with lower amounts of $\mathrm{T}_{\text {reg }}$ subgroups $\left(\mathrm{CD} 8^{+} \mathrm{T}_{\text {reg }}\right.$ and $\left.\mathrm{T}_{\text {eff } / \mathrm{em} \mathrm{reg}}\right)$ in unstimulated and even more in 'DC'-stimulated cases. 
A activation and proliferation

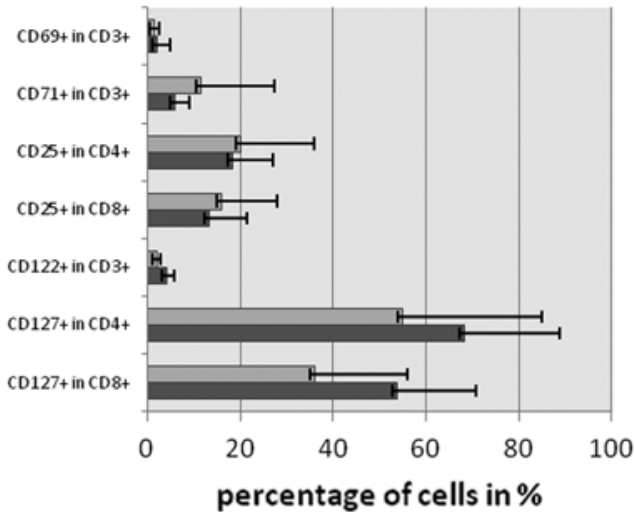

$B$ regulation
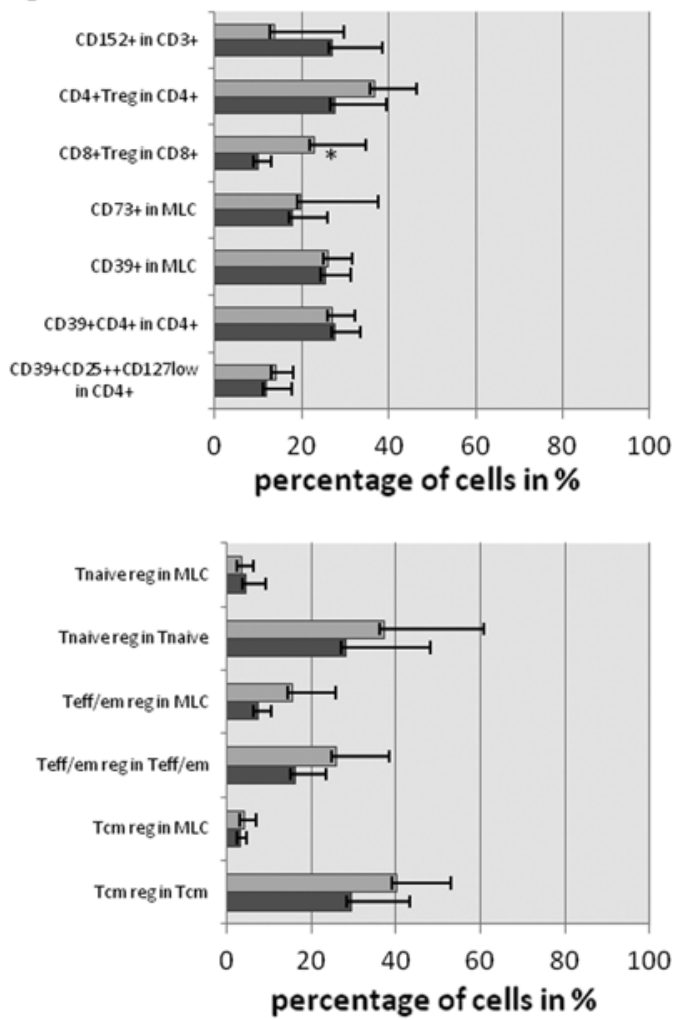

\footnotetext{
$\square$ 'non-lysis' $\square$ 'lysis'

${ }^{*} \mathrm{p}=0.05-0.1,{ }^{* *}=\mathrm{p}<0.05,{ }^{* * *}=\mathrm{p}<0.005$
}

after 'DC' stimulation
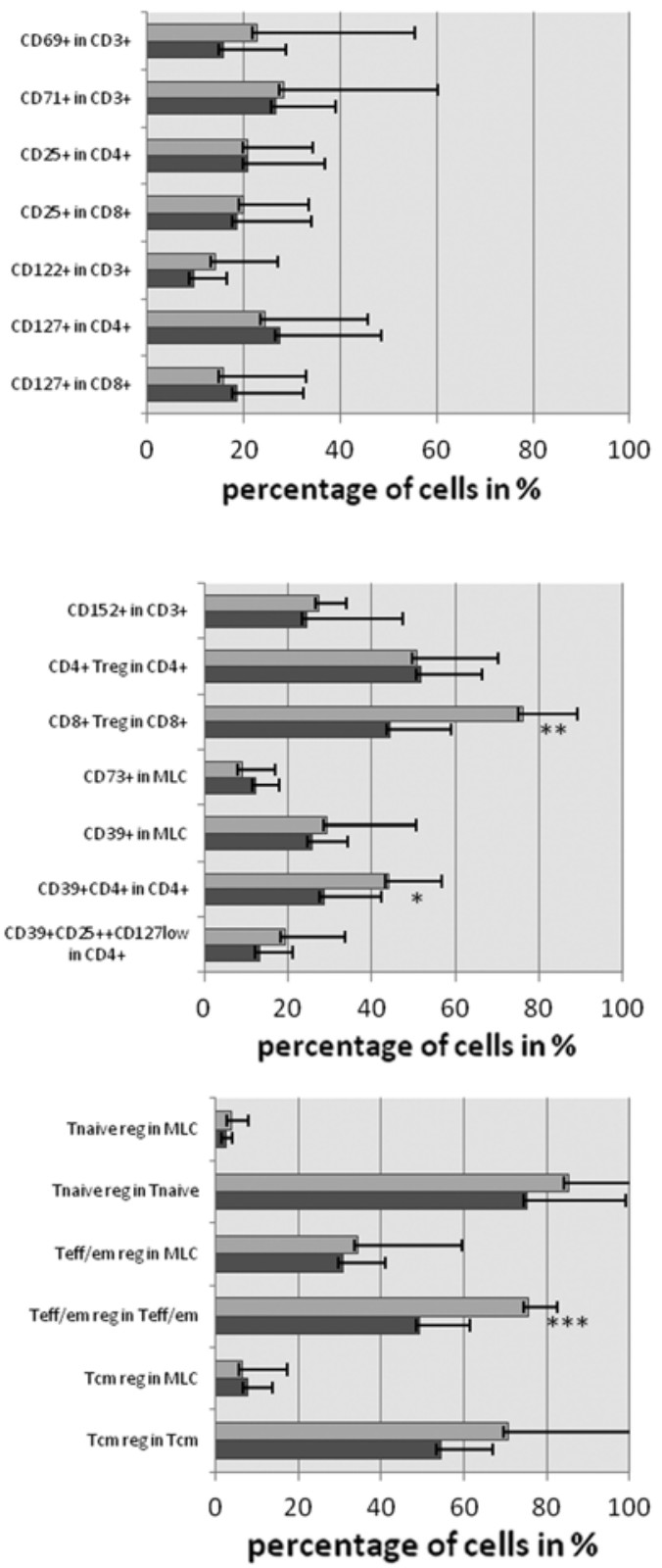

FIGURE 4. Correlation of T-cell subgroups with the antileukemic function of 'DC'-stimulated T cells in AML cases. Expression profiles of activation and proliferation markers (A) or regulation markers (B) on T cells from AML patients before (left side) or after 'DC' stimulation (right side) are given with cases subdivided into those with or without antileukemic functionality. AML indicates acute myeloid leukemia; DC, dendritic cells.

\section{DISCUSSION}

Regulatory $\mathrm{T}$ cells $\left(\mathrm{iT}_{\mathrm{reg}}\right.$ ) and their subgroups play a critical role in the mediation of immune responses. With respect to AML patients, the role of $T_{\text {reg }}$ is of special interest: on the one hand, the suppressive role of $T_{\text {reg }}$ and their ability to suppress lethal graft-versus-host disease could be demonstrated, ${ }^{35-37}$ but on the other, high
$\mathrm{T}_{\text {reg }}$ counts after SCT, respectively, after adoptive $\mathrm{T}_{\text {reg-cell }}$ transfer could be correlated with reduced graft-versusleukemia effects. ${ }^{38-40}$ Recently, our research group demonstrated that the conversion of leukemic blasts into leukemia-derived $\mathrm{DC}\left(\mathrm{DC}_{\mathrm{leu}}\right)$, being effective professional antigen-presenting cells by inducing activation, proliferation, and differentiation of naïve $\mathrm{T}$ cells into different 

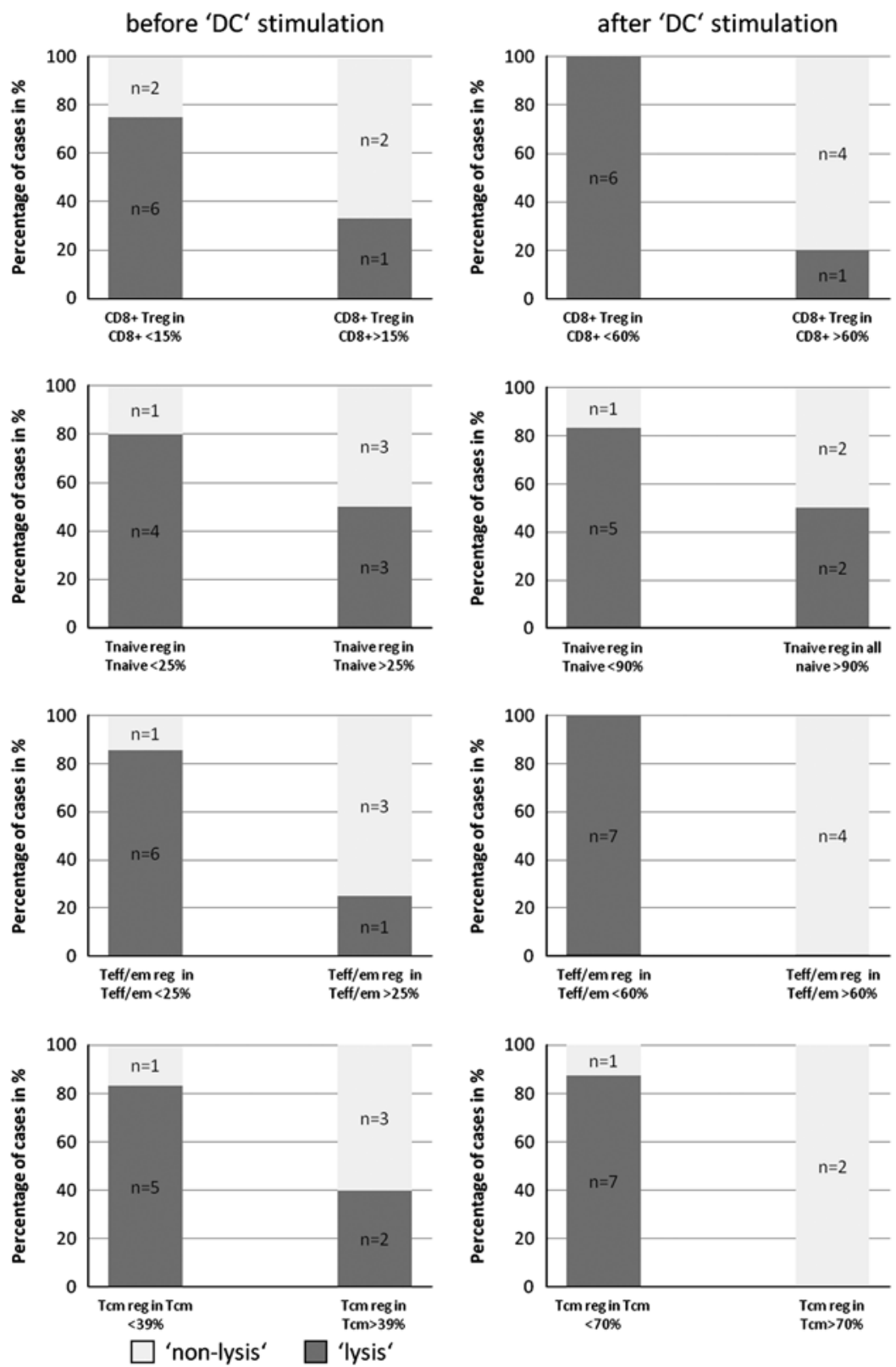

FIGURE 5. Cut-off values of $\mathrm{T}_{\text {reg }}$ subpopulations contribute to the prediction of the antileukemic reactivity of unstimulated and even more of 'DC'-stimulated T cells in AML cases. Proportions of selected $T_{\text {reg }}$ subtypes before (left side) or after 'DC' stimulation (right side) that correlate with the lytic or the nonlytic function of T cells are given. AML indicates acute myeloid leukemia; DC, dendritic cells.

effector $\mathrm{T}$ cells, can improve the mediation of an antileukemic T-cell response and provides a good ex vivo model to study stimulatory influences on $\mathrm{T}$ cells. ${ }^{30}$ To gain new insights into the role of $\mathrm{T}_{\text {reg }}$ and the mediation of antileukemic T-cell responses, we investigated the profile of unstimulated $\mathrm{T}$ cells, with ex vivo $\mathrm{DC}_{\text {leu }}$ containing $\mathrm{DC}$ ('DC') or leukemic blasts containing 'MNC'-stimulated $\mathrm{T}$ cells in AML patients compared with healthy probands. Finally, we correlated the $T_{\text {reg }}$ distribution with the mediation of an effective antileukemic T-cell cytotoxicity (lysis vs. nonlysis).

First of all, the present study confirms our former findings, showing that 'DC'-stimulated $\mathrm{T}$ cells improve the mediation of an antileukemic T-cell response compared with
'MNC'-stimulated T cells. The present study verified that unstimulated $\mathrm{T}$ cells showed a reduced induction of antileukemic cytotoxicity compared with 'DC'-stimulated T cells, but a higher percentage of antileukemic function compared with 'MNC'-stimulated T cells. ${ }^{30,31}$ These findings contribute to the assumption that the inhibitory microenvironment induced by blasts could be abolished after blast conversion to $\mathrm{DC}_{\text {leu. }} \cdot 2$

\section{General Activation and Proliferation After 'DC' or 'MNC' Stimulation}

T-cell stimulation with 'DC' or 'MNC' leads to a general T-cell activation and proliferation. ${ }^{31}$ During 'DC' or 'MNC' stimulation, we could observe an upregulation of 
activation and proliferation surface markers. According to former studies, we also found the typical pattern of an early upregulation of $\mathrm{CD} 9^{+}$already on day 1 and a delayed upregulation of the proliferation marker $\mathrm{CD} 71^{+}$, reaching the maximum expression on $\mathrm{T}$ cells on day $5.41,42$ The surface expression of $\mathrm{CD} 25^{+}$already had a relatively high base level on unstimulated $\mathrm{T}$ cells compared with other surface markers and showed no significant upregulation on activated T cells during the whole time course. Nguyen and colleagues postulated the coexpression of $\mathrm{CD}^{+} 1^{+}$and $\mathrm{CD}_{25^{+}}$as reliable markers for T-cell proliferation. Our data suggest the single expression of $\mathrm{CD} 71^{+}$as the most reliable marker to evaluate $\mathrm{T}$-cell proliferation. As already described, we could observe a downregulation of $\mathrm{CD} 127^{+}$, the IL-7-receptor, during T-cell proliferation. ${ }^{43,44}$ Our observation of a significantly higher surface expression of $\mathrm{CD} 127^{+}$on unstimulated $\mathrm{T}$ cells in healthy probands compared with AML patients might express the higher proliferation potential of healthy $\mathrm{T}$ cells compared with $\mathrm{T}$ cells in AML patients.

\section{$\mathrm{CD}^{+} \mathrm{CD}^{++} \mathrm{CD}^{+27^{\text {low }}} \mathrm{T}_{\text {reg }}$ Instead of FOXP3 ${ }^{+} \mathrm{T}_{\text {reg }}$}

Originally, $\mathrm{T}_{\text {reg }}$ were defined through the expression of the intracellular transcriptional factor $\mathrm{FOXP}^{+}$, which is an important regulator of the development and function of $T_{\text {reg }}$ and is classified as one of the most reliable $T_{\text {reg }}$ markers. ${ }^{21,45}$ However, several studies described the existence of suppressive $\mathrm{T}$ cells not expressing $\mathrm{FOXP}^{+}{ }^{46}$ Several studies have demonstrated a high correlation between the expression of $\mathrm{FOXP}^{+}$and the low surface expression of the IL-7 receptor $\alpha$ chain $\left(\mathrm{CD} 127^{\text {low }}\right)$ on $\mathrm{T}_{\text {reg. }}{ }^{47-49} \mathrm{It}$ is interesting to note that Hartigan-O'Connor et $\mathrm{al}^{49}$ found robustly suppressive $\mathrm{CD} 25^{+} \mathrm{CD} 127^{\text {low }} \mathrm{T}$ cells despite the low expression of FOXP3. Therefore, we decided to use CD127 $7^{\text {low }}$ as the $\mathrm{T}_{\text {reg }}$ marker in our model to address $\mathrm{FOXP}^{+}$and FOXP3-T reg. Moreover, by focusing on extracellular surface markers, our methodological procedures were not impaired through permeabilization techniques.

\section{High Counts of Distinct $\mathrm{T}_{\text {reg }}$ Subgroups Correlate With Cancer}

It has been demonstrated that increased frequencies of $\mathrm{T}_{\text {reg }}$ or a loss of $\mathrm{T}_{\text {reg-mediated immune tolerance correlates }}$ with several solid cancers and hematologic diseases. ${ }^{40}$ In the present study, we demonstrated that AML patients presented with significantly higher frequencies of several $\mathrm{T}_{\text {reg }}$ subgroups in unstimulated $\mathrm{T}$ cells compared with healthy probands, correlating with the findings of former studies. ${ }^{17,50}$ Shenghui et $\mathrm{al}^{51}$ have already shown that an elevated frequency of $\mathrm{T}_{\text {reg }}$ in the peripheral blood and bone marrow is associated with a poor prognosis in AML patients. However, although most of these studies were restricted to the well-investigated $\mathrm{CD} 4{ }^{+} \mathrm{CD} 25^{\text {high }} \mathrm{FOXP} 3^{+} \mathrm{T}_{\text {reg, }}$, there have been some recent reports of other subpopulations of clinically interesting regulatory $\mathrm{T}$ cells. Beside $\mathrm{CD}^{+} \mathrm{T}_{\text {reg, }}$, recently, the existence of cytotoxic $\mathrm{CD}^{+} \mathrm{T}$ cells was demonstrated, contradicting the paradigm of $\mathrm{CD}^{+} \mathrm{T}$-helper cells and $\mathrm{CD} 8^{+}$cytotoxic $\mathrm{T}$ cells (Steger B, unpublished data, 2012). Recently, more investigations have been conducted to determine the suppressive role of the less well-described $\mathrm{CD} 8^{+} \mathrm{T}_{\text {reg }}$ population in cancer. ${ }^{52,53}$ There is already increasing evidence indicating that $\mathrm{CD}^{+} \mathrm{T}_{\text {reg }}$ might accumulate in the tumor microenvironment in solid tumor diseases such as prostate or ovarian cancer. ${ }^{53-55}$ Moreover, Chaput et $\mathrm{al}^{56}$ demonstrated significantly higher proportions of circulating $\mathrm{CD} 8^{+} \mathrm{T}_{\text {reg }}$ in the peripheral blood of colon cancer patients compared with healthy probands. Actually, less is known about circulating $\mathrm{CD}^{+} \mathrm{T}_{\text {reg }}$ in $\mathrm{AML}$ patients' peripheral blood.

Recently, several working groups have described $\mathrm{T}_{\text {reg }}$ subgroups, consisting of phenotypically and functionally distinct subtypes such as naïve $T_{\text {reg }}$ and effector $T_{\text {reg }}$, because of their ability to differentiate into effector/memory cells after antigen contact. ${ }^{46,57-59}$ In the present study, we could demonstrate higher frequencies of $\mathrm{CD}^{+} \mathrm{T}_{\text {reg }}$ and $\mathrm{CD}^{+} \mathrm{T}_{\text {reg }}$ and also of $\mathrm{T}_{\text {naive reg, }}, \mathrm{T}_{\mathrm{cm} \text { reg, }}$, and $\mathrm{T}_{\text {eff }} / \mathrm{em}$ reg in AML patients compared with healthy probands. These findings implicate that regulatory and effector T-cell subsets have a greater plasticity than originally thought.

Another $\mathrm{T}_{\text {reg }}$ subgroup is defined to mediate the suppressive mechanism of adenosine produced through the ectoenzymes $\mathrm{CD}^{+} 9^{+}$(ectonucleoside triphosphate diphosphohydrolase) and $\mathrm{CD}^{+} 3^{+}$(ecto-5'-nucleotidase 1), which catalyze the sequential hydrolysis of $\mathrm{ATP} / \mathrm{ADP} .{ }^{60}$ In humans, the expression of $\mathrm{CD} 39^{+}$is found on B cells, leukemic blasts, and $\mathrm{T}$ cells and $\mathrm{T}_{\text {reg }}$ with restriction to $\mathrm{T}_{\text {eff } / \mathrm{em} \mathrm{reg.}}{ }^{26}$ Szczepanski et $\mathrm{al}^{17}$ have shown that $\mathrm{T}_{\text {reg }}$ in AML patients express CD39 ${ }^{+}$ and $\mathrm{CD}^{+} 3^{+}$and consequently hydrolyze ATP more efficiently than $T_{\text {reg }}$ in healthy probands. In unstimulated $T$ cells, we found a higher expression frequency of $\mathrm{CD}_{3} 9^{+}$and a lower expression frequency of $\mathrm{CD}^{+} 3^{+}$in $\mathrm{AML}$ patients compared with healthy probands as most of our patients were studied during chemotherapeutic treatment. These data indicate that because of tumor lysis effects, free nucleosides influence the surface expression frequencies of $\mathrm{CD} 39^{+}$and $\mathrm{CD}^{+} 3^{+}$in AML patients compared with healthy probands. Because of the different expression frequencies, we recommend the monitoring of CD39 ${ }^{+} \mathrm{T}_{\text {reg }}$ only in AML patients without high levels of free nucleotides (due to chemotherapeutic intervention).

CTLA4 $\left(\mathrm{CD} 152^{+}\right)$mediates suppression by binding to $\mathrm{CD}^{+} 0^{+}$and $\mathrm{CD}^{+} 6^{+}$on $\mathrm{DC}$, through which these costimulatory surface molecules for T-cell activation are reduced on DC. ${ }^{61}$ We could detect neither a significant difference in the surface expression profile of $\mathrm{CD}_{152}{ }^{+}$on healthy $\mathrm{T}_{\text {reg }}$ compared with the $\mathrm{T}_{\text {reg }}$ of AML patients nor an increase of this surface marker during DC or MNC stimulation. These findings suggest that in this setting, CTLA-4 does not play a crucial role. Similar findings have been reported formerly. ${ }^{62}$

\section{Kinetic Development of $\mathrm{T}_{\text {reg }}$ Subgroups Under Stimulation}

The common problem of all $\mathrm{T}_{\text {reg }}$ markers is their general upregulation on activated $\mathrm{T}$ cells, which reduces their specific correlation to $\mathrm{T}_{\text {reg }}$. Recent publications have also shown a general in vitro expansion of $\mathrm{CD}^{+} \mathrm{T}_{\text {reg }}$ by 'DC' stimulation during MLC. ${ }^{63}$ Mahic et al ${ }^{64}$ demonstrated an increase in $\mathrm{CD}^{+} \mathrm{T}_{\text {reg }}$ by continuous antigen stimulation. During 'DC' or 'MNC' stimulation, we found a continuous increase in most of the $T_{\text {reg }}$ subgroups in AML patients and in healthy probands. After stimulation by MLC, we still found significantly higher levels of $\mathrm{T}_{\mathrm{cm} \text { reg }}$ and $\mathrm{T}_{\text {eff }} / \mathrm{em}$ reg and tendentially higher levels of $\mathrm{CD} 4^{+}$and $\mathrm{CD}^{+} \mathrm{T}_{\text {reg }}$ in $\mathrm{AML}$ patients compared with healthy probands.

Previous data of our group showed an upregulation of $\mathrm{CD} 9^{+}$during ex vivo of healthy T cells with nucleosides, whereas the expression of $\mathrm{CD}^{+} 3^{+}$was downregulated (Weiler M, unpublished data). During 'DC' and 'MNC' 
stimulation, in the present study, we also observed an upregulation of $\mathrm{CD}_{3} 9^{+}$and a downregulation of $\mathrm{CD}^{+} 3^{+}$in healthy probands. It is interesting to note that AML patients did not show significant changes in the expression frequencies of $\mathrm{CD}_{3} 9^{+}$and $\mathrm{CD}^{+} 3^{+}$during stimulation, probably due to a high expression of $\mathrm{CD} 39^{+}$and a low expression of $\mathrm{CD}^{+} 3^{+}$antigens before culture.

\section{The Antileukemic Functionality Correlates With Frequencies of $T_{\text {reg }}$}

Our data showed that an antileukemic T-cell response was achieved in $60 \%$ of AML cases after 'DC' stimulation compared with $40 \%$ after 'MNC' stimulation. Consequently, 'DC' stimulation seems to be an option to reverse $\mathrm{T}$-cell anergy and to reestablish an antileukemic $\mathrm{T}$ cell response, as already shown by our group. ${ }^{29,30}$ In the context of the present study, we could correlate differences in $\mathrm{T}_{\text {reg }}$ profiles with the antileukemic functionality after 'DC', but not after 'MNC' stimulation. Moreover, ex vivo cut-off values predicting the antileukemic functionality were definable. The present study could demonstrate significantly higher proportions of $\mathrm{CD}^{+} \mathrm{T}_{\text {reg }}$ and $\mathrm{T}_{\mathrm{eff} / \mathrm{em} \text { reg in }}$ the nonlysis group compared with the lysis group after 'DC' stimulation. The expression frequencies of these $T_{\text {reg }}$ subgroups in the lysis group were comparable to the expression frequencies in our healthy probands. Surprisingly, we could not detect any correlations in the proportions of $\mathrm{CD}^{+} \mathrm{T}_{\text {reg }}$ with the lysis or the nonlysis group.

\section{CONCLUSIONS}

In summary, our results provide new insights into the cellular profiles and the antileukemic T-cell functionality of $\mathrm{T}_{\text {reg. }}$. Our findings suggest a crucial role of $\mathrm{CD} 8^{+} \mathrm{T}_{\text {reg }}$ and $\mathrm{T}_{\text {eff/em reg }}$ in the mediation of the immune escape in AML patients. Moreover, we showed that frequencies of distinctly decreased levels of $T_{\text {reg }}$ subtypes correlate with the reestablishment of the antileukemic functionality in a significant proportion of patients. We could even define cut-off values for $\mathrm{T}_{\text {reg }}$ subtypes, which allow an estimation of the lytic potential of individual patients' $\mathrm{T}$ cells. CD39 ${ }^{+}$and $\mathrm{CD}^{+} 3^{+}$expression on $\mathrm{T}_{\text {reg }}$ subgroups have to be discussed critically in patients with a high cellular turnover because of chemotherapy.

From a clinical point of view, our data recommend the monitoring of the distinct $\mathrm{T}_{\text {reg }}$ subgroups $\left(\mathrm{CD} 8^{+} \mathrm{T}_{\text {reg }}\right.$, and $\mathrm{T}_{\text {eff }} / \mathrm{em}$ reg ) and defining cut-off values in vivo. In the context of immunotherapeutic strategies, further experiments are necessary to learn about mechanisms involved in the suppression of antileukemic graft-versus-leukemia reactions and to create strategies to manipulate $T_{\text {reg }}$ subtypes (eg, by abolishing an inhibitory blast microenvironment in vivo) or to learn about mechanisms responsible for diminished graft versus host reactions and to manipulate them (eg, by elimination of autoreactive $\mathrm{T}$ cells).

\section{ACKNOWLEDGMENTS}

The authors thank patients, nurses and physicians on the wards for their support and diagnostic laboratories for the contribution of diagnostic reports of the patients. Moreover, the authors thank all of the colleagues for helpful discussion. Parts of the results presented in this manuscript were worked out in the course of the MD thesis of Julia Schick and Valentin Vogt at the University of Munich and the Helmholtz-Centre Munich.

\section{CONFLICTS OF INTEREST/FINANCIAL DISCLOSURE}

All authors have declared there are no financial conflicts of interest in regards to this work.

\section{REFERENCES}

1. Giles FJ. New drugs in acute myeloid leukemia. Curr Oncol Rep. 2002;5:369-374.

2. Jabbour EJ, Estey E, Kantarjian HM. Adult acute myeloid leukemia. Mayo Clin Proc. 2006;2:247-260.

3. Scholl N, Loibl J, Kremser A, et al. The role of soluble and cell-surface expressed 4-1BB ligand in patients with malignant hemopoietic disorders. Leuk Lymphoma. 2009;3:427-436.

4. Tait BD. HLA class I expression on human cancer cells. Implications for effective immunotherapy. Hum Immunol. 2000;2:158-165.

5. van Luijn MM, van den Ancker W, Chamuleau ME, et al. Impaired antigen presentation in neoplasia: basic mechanisms and implications for acute myeloid leukemia. Immunotherapy. 2010;1:85-97.

6. Cormier JN, Panelli MC, Hackett JA, et al. Natural variation of the expression of HLA and endogenous antigen modulates CTL recognition in an in vitro melanoma model. Int J Cancer. 1999;5:781-790.

7. Salih HR, Schmetzer HM, Burke C, et al. Soluble CD137 (4-1BB) ligand is released following leukocyte activation and is found in sera of patients with hematological malignancies. J Immunol. 2001;7:4059-4066.

8. Mahic M, Yaqub S, Bryn T, et al. Differentiation of naive $\mathrm{CD}^{+} \mathrm{T}$ cells into $\mathrm{CD}^{+} \mathrm{CD}^{25+} \mathrm{FOXP}^{+}$regulatory $\mathrm{T}$ cells by continuous antigen stimulation. $J$ Leukoc Biol. 2008;5: 1111-1117.

9. Baecher-Allan C, Brown JA, Freeman GJ, et al. CD4 ${ }^{+}$ CD25 high regulatory cells in human peripheral blood. J Immunol. 2001;3:1245-1253.

10. Lindley S, Dayan CM, Bishop A, et al. Defective suppressor function in CD4(+)CD25(+) T-cells from patients with type 1 diabetes. Diabetes. 2005;1:92-99.

11. Bladon J, Taylor PC. Extracorporeal photopheresis induces apoptosis in the lymphocytes of cutaneous T-cell lymphoma and graft-versus-host disease patients. Br J Haematol. 1999; 4:707-711.

12. Zhang H, Podojil JR, Chang J, et al. TGF-beta-induced myelin peptide-specific regulatory $\mathrm{T}$ cells mediate antigen-specific suppression of induction of experimental autoimmune encephalomyelitis. J Immunol. 2010;12:6629-6636.

13. DiPaolo RJ, Brinster C, Davidson TS, et al. Autoantigenspecific TGFbeta-induced Foxp $3^{+}$regulatory $\mathrm{T}$ cells prevent autoimmunity by inhibiting dendritic cells from activating autoreactive T cells. J Immunol. 2007;7:4685-4693.

14. Bennett CL, Christie J, Ramsdell F, et al. The immune dysregulation, polyendocrinopathy, enteropathy, X-linked syndrome (IPEX) is caused by mutations of FOXP3. Nat Genet. 2001;1:20-21.

15. Wildin RS, Ramsdell F, Peake J, et al. X-linked neonatal diabetes mellitus, enteropathy and endocrinopathy syndrome is the human equivalent of mouse scurfy. Nat Genet. 2001;1: 18-20.

16. Zhou Q, Bucher C, Munger ME, et al. Depletion of endogenous tumor-associated regulatory $\mathrm{T}$ cells improves the efficacy of adoptive cytotoxic T-cell immunotherapy in murine acute myeloid leukemia. Blood. 2009;18:3793-3802.

17. Szczepanski MJ, Szajnik M, Czystowska M, et al. Increased frequency and suppression by regulatory $\mathrm{T}$ cells in patients with acute myelogenous leukemia. Clin Cancer Res. 2009; 10:3325-3332.

18. Mougiakakos D, Choudhury A, Lladser A, et al. Regulatory T cells in cancer. Adv Cancer Res. 2010;57-117.

19. Sakaguchi S, Sakaguchi N, Asano M, et al. Immunologic selftolerance maintained by activated $\mathrm{T}$ cells expressing IL-2 
receptor alpha-chains (CD25). Breakdown of a single mechanism of self-tolerance causes various autoimmune diseases. J Immunol. 1995;3:1151-1164.

20. Hori S, Nomura T, Sakaguchi S. Control of regulatory T cell development by the transcription factor Foxp3. Science. 2003;5609:1057-1061.

21. Fontenot JD, Gavin MA, Rudensky AY. Foxp3 programs the development and function of CD4+CD25+ regulatory T cells. Nat Immunol. 2003;4:330-336.

22. Corthay A. How do regulatory T cells work? Scand J Immunol. 2009;4:326-336

23. Pyzik M, Piccirillo CA. TGF-beta1 modulates Foxp3 expression and regulatory activity in distinct CD4 $+\mathrm{T}$ cell subsets. J Leukoc Biol. 2007;2:335-346.

24. Nakamura K, Kitani A, Strober W. Cell contact-dependent immunosuppression by $\mathrm{CD} 4(+) \mathrm{CD} 25(+)$ regulatory $\mathrm{T}$ cells is mediated by cell surface-bound transforming growth factor beta. J Exp Med. 2001;5:629-644.

25. Grossman WJ, Verbsky JW, Barchet W, et al. Human T regulatory cells can use the perforin pathway to cause autologous target cell death. Immunity. 2004;4:589-601.

26. Borsellino G, Kleinewietfeld M, Di Mitri D, et al. Expression of ectonucleotidase CD39 by Foxp3+ Treg cells: hydrolysis of extracellular ATP and immune suppression. Blood. 2007; 4:1225-1232.

27. Kobie JJ, Shah PR, Yang L, et al. T regulatory and primed uncommitted CD4 T cells express CD73, which suppresses effector CD4 $\mathrm{T}$ cells by converting $5^{\prime}$-adenosine monophosphate to adenosine. $J$ Immunol. 2006;10:6780-6786.

28. Fallarino F, Grohmann U, Hwang KW, et al. Modulation of tryptophan catabolism by regulatory $\mathrm{T}$ cells. Nat Immunol. 2003; 12:1206-1212.

29. Schmetzer HM. Antileukemic T-cell-mediated immune reactions: limitations and perspectives for future therapies. Immunotherapy. 2011;7:809-811.

30. Grabrucker C, Liepert A, Dreyig J, et al. The quality and quantity of leukemia-derived dendritic cells from patients with acute myeloid leukemia and myelodysplastic syndrome are a predictive factor for the lytic potential of dendritic cells-primed leukemia-specific T cells. J Immunother. 2010;5: 523-537.

31. Liepert A, Grabrucker C, Kremser A, et al. Quality of T-cells after stimulation with leukemia-derived dendritic cells (DC) from patients with acute myeloid leukemia (AML) or myeloid dysplastic syndrome (MDS) is predictive for their leukemia cytotoxic potential. Cell Immunol. 2010;1:23-30.

32. Kremser A, Dressig J, Grabrucker C, et al. Dendritic cells (DCs) can be successfully generated from leukemic blasts in individual patients with AML or MDS: an evaluation of different methods. J Immunother. 2010;2:185-199.

33. Dreyssig J, Kremser A, Liepert A, et al. Various "dendritic cell antigens" are already expressed on uncultured blasts in acute myeloid leukemia and myelodysplastic syndromes. Imтипоtherapy. 2011;9:1113-1124.

34. Schmetzer HM, Kremser A, Loibl J, et al. Quantification of ex vivo generated dendritic cells (DC) and leukemia-derived DC contributes to estimate the quality of DC, to detect optimal DC-generating methods or to optimize DC-mediated T-cellactivation-procedures ex vivo or in vivo. Leukemia. 2007;6: $1338-1341$.

35. Taylor PA, Lees CJ, Blazar BR. The infusion of ex vivo activated and expanded $\mathrm{CD} 4(+) \mathrm{CD} 25(+)$ immune regulatory cells inhibits graft-versus-host disease lethality. Blood. 2002; 10:3493-3499.

36. Edinger M, Hoffmann P, Ermann J, et al. CD4+CD25+ regulatory $\mathrm{T}$ cells preserve graft-versus-tumor activity while inhibiting graft-versus-host disease after bone marrow transplantation. Nat Med. 2003;9:1144-1150.

37. Hoffmann $\mathrm{P}$, Ermann $\mathrm{J}$, Edinger $\mathrm{M}$, et al. Donor-type $\mathrm{CD} 4(+) \mathrm{CD} 25(+)$ regulatory $\mathrm{T}$ cells suppress lethal acute graftversus-host disease after allogeneic bone marrow transplantation. J Exp Med. 2002;3:389-399.
38. Jones SC, Murphy GF, Korngold R. Post-hematopoietic cell transplantation control of graft-versus-host disease by donor CD425 $\mathrm{T}$ cells to allow an effective graft-versusleukemia response. Biol Blood Marrow Transplant. 2003; 4:243-256.

39. Trenado A, Charlotte F, Fisson S, et al. Recipient-type specific $\mathrm{CD} 4+\mathrm{CD} 25+$ regulatory $\mathrm{T}$ cells favor immune reconstitution and control graft-versus-host disease while maintaining graftversus-leukemia. J Clin Invest. 2003;11:1688-1696.

40. Beyer M, Schultze JL. Regulatory T cells in cancer. Blood. 2006;3:804-811.

41. Sancho D, Gomez M, Sanchez-Madrid F. CD69 is an immunoregulatory molecule induced following activation. Trends Immunol. 2005;3:136-140.

42. Nguyen XD, Eichler H, Dugrillon A, et al. Flow cytometric analysis of $\mathrm{T}$ cell proliferation in a mixed lymphocyte reaction with dendritic cells. J Immunol Methods. 2003;1-2:57-68.

43. Xue HH, Kovanen PE, Pise-Masison CA, et al. IL-2 negatively regulates IL-7 receptor alpha chain expression in activated T lymphocytes. Proc Natl Acad Sci U S A. 2002;21: 13759-13764.

44. Foxwell BM, Taylor-Fishwick DA, Simon JL, et al. Activation induced changes in expression and structure of the IL-7 receptor on human T cells. Int Immunol. 1992;2:277-282.

45. Sakaguchi S, Miyara M, Costantino CM, et al. FOXP3+ regulatory $\mathrm{T}$ cells in the human immune system. Nat Rev Immunol. 2010;7:490-500.

46. Miyara M, Yoshioka Y, Kitoh A, et al. Functional delineation and differentiation dynamics of human $\mathrm{CD} 4+\mathrm{T}$ cells expressing the FoxP3 transcription factor. Immunity. 2009;6: 899-911.

47. Liu W, Putnam AL, Xu-Yu Z, et al. CD127 expression inversely correlates with FoxP3 and suppressive function of human CD4+ T reg cells. J Exp Med. 2006;7:1701-1711.

48. Seddiki N, Santner-Nanan B, Martinson J, et al. Expression of interleukin (IL)-2 and IL-7 receptors discriminates between human regulatory and activated $\mathrm{T}$ cells. $J$ Exp Med. 2006; 7:1693-1700.

49. Hartigan-O'Connor DJ, Poon C, Sinclair E, et al. Human CD4+ regulatory T cells express lower levels of the IL-7 receptor alpha chain (CD127), allowing consistent identification and sorting of live cells. J Immunol Methods. 2007;1-2:41-52.

50. Wang $X$, Zheng $J$, Liu $J$, et al. Increased population of CD4(+)CD25(high), regulatory $T$ cells with their higher apoptotic and proliferating status in peripheral blood of acute myeloid leukemia patients. Eur J Haematol. 2005;6:468-476.

51. Shenghui Z, Yixiang H, Jianbo W, et al. Elevated frequencies of $\mathrm{CD} 4 \mathrm{CD} 25 \mathrm{CD} 127$ lo regulatory $\mathrm{T}$ cells is associated to poor prognosis in patients with acute myeloid leukemia. Int $J$ Cancer. 2010;6:1373-1381.

52. Smith TR, Kumar V. Revival of CD8+ Treg-mediated suppression. Trends Immunol. 2008;7:337-342.

53. Wang RF. CD8+ regulatory $\mathrm{T}$ cells, their suppressive mechanisms, and regulation in cancer. Hum Immunol. 2008; 11:811-814.

54. Joosten SA, van Meijgaarden KE, Savage ND, et al. Identification of a human CD8+ regulatory $\mathrm{T}$ cell subset that mediates suppression through the chemokine CC chemokine ligand 4. Proc Natl Acad Sci U S A. 2007;19:8029-8034.

55. Wei S, Kryczek I, Zou L, et al. Plasmacytoid dendritic cells induce CD8+ regulatory T cells in human ovarian carcinoma. Cancer Res. 2005;12:5020-5026.

56. Chaput N, Louafi S, Bardier A, et al. Identification of CD8 + CD25+ Foxp3+ suppressive T cells in colorectal cancer tissue. Gut. 2009;4:520-529.

57. Kleinewietfeld M, Puentes F, Borsellino G, et al. CCR6 expression defines regulatory effector/memory-like cells within the CD25(+)CD4+ T-cell subset. Blood. 2005;7: 2877-2886.

58. Seddiki N, Santner-Nanan B, Tangye SG, et al. Persistence of naive CD45RA+ regulatory $\mathrm{T}$ cells in adult life. Blood. 2006; 7:2830-2838 
59. Valmori D, Merlo A, Souleimanian NE, et al. A peripheral circulating compartment of natural naive CD4 Tregs. J Clin Invest. 2005; 7:1953-1962.

60. Hasko G, Linden J, Cronstein B, et al. Adenosine receptors: therapeutic aspects for inflammatory and immune diseases. Nat Rev Drug Discov. 2008;9:759-770.

61. Andre S, Tough DF, Lacroix-Desmazes S, et al. Surveillance of antigen-presenting cells by $\mathrm{CD} 4+\mathrm{CD} 25+$ regulatory $\mathrm{T}$ cells in autoimmunity: immunopathogenesis and therapeutic implications. Am J Pathol. 2009;5:1575-1587.
62. Tang Q, Boden EK, Henriksen KJ, et al. Distinct roles of CTLA-4 and TGF-beta in CD4+CD25+ regulatory $\mathrm{T}$ cell function. Eur J Immunol. 2004;11:2996-3005.

63. Yamazaki S, Inaba K, Tarbell KV, et al. Dendritic cells expand antigen-specific Foxp3+ CD25+ CD4+ regulatory $\mathrm{T}$ cells including suppressors of alloreactivity. Immunol Rev. 2006;314-329.

64. Mahic M, Henjum K, Yaqub S, et al. Generation of highly suppressive adaptive $\mathrm{CD} 8(+) \mathrm{CD} 25(+) \mathrm{FOXP} 3(+)$ regulatory $\mathrm{T}$ cells by continuous antigen stimulation. Eur $J$ Immunol. 2008;3:640-646. 